\title{
Jurisdiction, Merits, and Non-Extant Rights
}

\author{
Howard M. Wasserman ${ }^{*}$
}

\section{INTRODUCTION}

Congressional threats against the jurisdiction of federal courts date to the early days of the Union. ${ }^{1}$ The threat even has its own pithy nickname - jurisdiction stripping - to describe congressional efforts to reduce or eliminate the power of the United States Supreme Court and the lower federal courts to hear and resolve particular classes of controversial federal constitutional claims. ${ }^{2}$ The scope of congressional power to jurisdiction-strip remains the great, heretofore unresolved, debate among procedure and constitutional law scholars, as well as the courts. ${ }^{3}$

* Associate Professor of Law, FIU College of Law; Visiting Associate Professor of Law, Saint Louis University School of Law, 2007-08. My thanks to Mike Allen, Kevin Clermont, Scott Dodson, Michael Dorf, David Fontana, Michael Gerhardt, Joel Goldstein, Matthew Mirow, Robert Pushaw, Rocky Rhodes, Glen Staszewski, Ellen Sward, and Jay Tidmarsh for thoughts and comments on drafts. My thanks to the faculties at Marquette Law School and William Mitchell College of Law for comments on presentations of this Article.

1. See Akhil Reed Amar, The Two-Tiered Structure of the Judiciary Act of 1789, 138 U. PA. L. REV. 1499, 1499-1500 (1990) ("From the First Judiciary Act on, this question has periodically occupied center stage in the high drama of national politics."); Gerald Gunther, Congressional Power to Curtail Federal Court Jurisdiction: An Opinionated Guide to the Ongoing Debate, 36 STAN. L. REV. 895, 896 (1984) ("Jurisdiction-curbing proposals have surfaced in Congress in virtually every period of controversial federal court decisions.").

2. See John A. Ferejohn \& Larry D. Kramer, Independent Judges, Dependent Judiciary: Institutionalizing Judicial Restraint, 77 N.Y.U. L. REV. 962, 986-87 (2002) (“[M]ost discussions of congressional regulation dwell on laws that deprive federal judges of power to hear a particular case or class of cases because of its controversial nature, or what has come to be known as "jurisdiction stripping."'); see also Amar, supra note 1, at 1499-1500 (identifying controversial issues at play in the jurisdiction-stripping controversy, such as abortion and flag burning); Gunther, supra note 1, at 895 (stating that most of the jurisdiction-stripping proposals of the early 1980s "stem from dissatisfaction with Supreme Court decisions, especially those dealing with ... controversial "social issues' such as school prayer, abortion, and busing" as a remedy in school desegregation); Judith Resnik, Trial as Error, Jurisdiction as Injury: Transforming the Meaning of Article III, 113 HARV. L. REv. 924, 980 (2000) ("Protesting federal jurisdiction can also be a way to object to an underlying legal norm ....").

3. See, e.g., Martin H. Redish, Federal Jurisdiction: Tensions in the Allocation of POWER 25 (2d ed. 1990) (describing "significant case law" indicating that "Congress has significant power to prohibit the Supreme Court from taking jurisdiction over cases allocated to its appellate jurisdiction"); $i d$. at 29 (describing argument that, because Congress need not have created lower federal courts, it could create such courts, but limit their jurisdiction); Akhil Reed Amar, A Neo- 
Never killed and buried, ${ }^{4}$ the controversy has returned in force in recent years amid congressional rumblings about bringing an "out-ofcontrol" judiciary to heel. ${ }^{5}$ In Hamdan v. Rumsfeld, ${ }^{6}$ the Court interpreted its way out of a potential jurisdiction strip expressly to avoid "grave questions about Congress' authority to impinge upon th[e]

Federalist View of Article III: Separating the Two Tiers of Federal Jurisdiction, 65 B.U. L. REV. 205, 229-30 (1985) (arguing that the federal judiciary, consisting of the Supreme Court and any lower federal courts, must have an original or appellate opportunity to hear any cases involving federal questions); Theodore Eisenberg, Congressional Authority to Restrict Federal Court Jurisdiction, 83 YALE L.J. 498, 504 (1974) (arguing that "because of changing circumstances, the framers' aspirations for the national judiciary cannot be fulfilled today without lower federal courts"); Gunther, supra note 1, at 921 (arguing against jurisdiction-stripping enactments "because they are unwise and violate the 'spirit' of the Constitution, even though they are ... within the sheer legal authority of Congress"); Henry Hart, The Power of Congress to Limit the Jurisdiction of Federal Courts: An Exercise in Dialectic, 66 HARV. L. REV. 1362, 1365 (1953) (arguing that any exceptions to jurisdiction "must not be such as will destroy the essential role of the Supreme Court in the constitutional plan"); Lawrence Gene Sager, Foreword: Constitutional Limitations on Congress' Authority to Regulate the Jurisdiction of the Federal Courts, 95 HARV. L. REV. 17, 65 (1981) (arguing that limits on congressional power "are crossed when Congress attempts to divest the Supreme Court, and all other federal courts, of jurisdiction at least to review state court decisions on constitutional challenges to governmental behavior"); id. at 76-77 ("When Congress manipulates jurisdiction in an effort to deny recognition and judicial enforcement of constitutional rights, it has deliberately set itself against the Constitution as the Court understands that document."). For recent innovative additions to the debate, see Laurence Claus, Constitutional Guarantees of the Judiciary: Jurisdiction, Tenure, and Beyond, 54 AM. J. COMP. L. 459, 460 (Supp. 2006) ("[T] he text seems to guarantee that one supreme Court will hold a power of ultimate judgment over every dispute that parties choose to litigate, so long as that dispute is one to which Article III extends the judicial Power of the United States."); Laurence Claus, The One Court That Congress Cannot Take Away: Singularity, Supremacy, and Article III, 96 GEO. L.J. 59, 64 (2007) ("Congress cannot use its Exceptions power to achieve particular desired answers to questions that fall within the judicial Power of the United States."); infra notes 232-42 and accompanying text.

4. See Charles G. Geyh, Judicial Independence, Judicial Accountability, and the Role of Constitutional Norms in Congressional Regulation of the Courts, 78 IND. L.J. 153, 165 (2003) ("To the extent that Congress has, as a matter of 'constitutional custom,' declined to impeach unpopular judges, to court-pack, or jurisdiction-strip because it has long regarded such practices as antithetical to Article III independence, the stature and stability of Congress's self-restraint is logically enhanced."); Sager, supra note 3, at 20 ("In large measure, our failure to lay these questions to rest is the product of the mutual respect and self-restraint that have characterized the behavior of Congress and of the Supreme Court in their dealings with one another.").

5. See larry D. Kramer, The People Themselves: Popular Constitutionalism and JUDICIAL REVIEW 249-51 (2004) (discussing use of blunt political tools to establish control and accountability in federal courts); Ferejohn \& Kramer, supra note 2, at 984 ("When we turn to Congress, moreover, we find a wide array of tools available to rein in a rambunctious judiciary."); Helen Norton, Reshaping Federal Jurisdiction: Congress's Latest Challenge to Judicial Review, 41 WAKE FOREST L. REV. 1003, 1018 (2006) (arguing that jurisdiction-stripping efforts are animated by the perception of 'federal courts' disregard for 'the people's' understanding of fundamental constitutional and/or moral principles"); Caprice L. Roberts, Jurisdiction Stripping in Three Acts: A Three String Serenade, 51 VILL. L. REV. 593, 631 (2006) (describing arguments that "[f]ederal courts have run amok and tilted the balance of power among the three branches too far" and that "Congress had to act in order to stop the despotism of the federal judicial bench"); Sager, supra note 3 , at 38 ("Perhaps Congress' power to regulate jurisdiction ought to be understood as its final trump, as an appropriate way for the national legislature to curb a judiciary run amok.").

6. Hamdan v. Rumsfeld, 126 S. Ct. 2749 (2006). 
Court's appellate jurisdiction."7 The Military Commissions Act of 2006 explicitly stripped the federal courts of jurisdiction over habeas corpus petitions and all other claims against the United States or its officers and agents brought by individuals detained by the United States and determined by the United States to be enemy combatants. ${ }^{8}$

More common efforts at jurisdiction stripping seek to remove particular, controversial federal constitutional issues from the scope of the federal courts' otherwise broad general federal question jurisdiction. Consider some recent examples. In the 109th Congress, there was the Constitution Restoration Act of 2005, which would have deprived federal courts of original and appellate jurisdiction to hear any claim against a government entity or officer for the "acknowledgement of God as the sovereign source of law, liberty, or government." In the 110th Congress, there is the We the People Act, which would deprive federal courts of power to adjudicate "laws, regulations, or policies of any State or unit of local government relating to the free exercise or establishment of religion. ${ }^{10}$ Such bills historically have gone nowhere, ${ }^{11}$ although some recent proposals passed in the Republican-controlled House of Representatives, perhaps indicating a sea change in interbranch relations at least in one house of Congress. ${ }^{12}$

7. Id. at 2763-64, 2769 (holding that jurisdiction-stripping provision did not apply retroactively).

8. Military Commissions Act of 2006, Pub. L. No. 109-366, § 7(a), 120 Stat. 2600, 2635-36 (2006). The Supreme Court likely will pass on the validity of this jurisdiction-stripping provision during the October Term 2007. See Boumediene v. Bush, 476 F.3d 981 (D.C. Cir. 2007), cert granted, Al Odah v. United States, 127 S. Ct. 3067 (2007).

9. S. 520, 109th Cong. $\S \S 101-02$ (2005). Another example was the Marriage Protection Act of 2007, which would deprive federal courts of original and appellate jurisdiction "to hear or decide any question pertaining to the interpretation of, or the validity under the Constitution of," the Defense of Marriage Act. Marriage Protection Act of 2007, H.R. 724, 110th Cong. § 2(a) (2007). The Defense of Marriage Act, enacted in 1996, provides that states need not give full faith and credit to same-sex marriages valid in other states. 28 U.S.C. $§ 1738 \mathrm{C}(2000)$.

10. We the People Act, H.R. 300, 110th Cong. § 3(1)(A) (2007). The bill also would have stripped federal jurisdiction to adjudicate privacy and equal protection claims related to sexual orientation, sexual practices, and the right to marry. Id. $\S \S 3(1)(\mathrm{B})-(\mathrm{C})$.

11. See Ferejohn \& Kramer, supra note 2, at 988 ("The chronic failure of these efforts to divest federal courts of jurisdiction easily could mislead one into believing that Congress cannot, as a practical matter, effectively control federal judges by regulating their jurisdiction."); Michael J. Gerhardt, What's Old Is New Again, 86 B.U. L. REV. 1267, 1280 (2006) ("[T]he failure of these measures may reflect the ongoing acceptance within the House of a constitutional norm against legislation that would directly interfere with judicial decisions or decision making."); Sager, supra note 3, at 20 (arguing that, although jurisdiction-stripping measures have been proposed, "Congress has almost always repudiated such efforts").

12. James E. Pfander, Federal Supremacy, State Court Inferiority, and the Constitutionality of Jurisdiction-Stripping Legislation, 101 Nw. U. L. REV. 191, 193-94 (2007) (calling the adoption of some stripping provisions in the House "something of a watershed in the history of Congress's relationship with the federal courts"); Norton, supra note 5, at 1003-04. For example, the Pledge 
A distinct, but too often conflated, way to restrict the reach and impact of federal judicial power is to reduce, limit, or eliminate the substantive constitutional, statutory and common law rights that are enforced in federal courts. ${ }^{13}$ The result is that enforceable substantive rights cease to exist or never come into existence under applicable legal rules. ${ }^{14}$ Non-existence is obvious if, for example, we imagine $A$ seeking relief against $B$ on rights purportedly established in a piece of federal legislation that never was enacted into law in accordance with constitutional requirements of bicameral passage and presidential approval. $^{15}$ The same is true if the right-creating legislation, although enacted, is constitutionally invalid. ${ }^{16}$ I suggest going further. We can define a right as non-extant any time the legal rule $A$ seeks to enforce against $B$ is not broad enough to be implicated by the actors, conduct, and events at issue. Any claim of right on such a non-extant legal rule must fail on the merits, because under applicable, controlling legal rules, $A$ cannot sue $B$ (at least not successfully) for $B$ 's conduct. ${ }^{17}$

Stripping jurisdiction and narrowing or eliminating (stripping, if you will) substantive rights arguably produces identical results-imposing "door-closing and access-limiting rules" 18 or rules that limit "decision making opportunities" for federal courts. ${ }^{19}$ Commentators $^{20}$ and courts ${ }^{21}$

Protection Act of 2005 (introduced in both the House and Senate) would have deprived the Supreme Court and lower federal courts of authority "to hear or decide any question pertaining to the interpretation of, or the validity under the Constitution of, the Pledge of Allegiance... or its recitation." Pledge Protection Act of 2005, H.R. 2389, 109th Cong. (2005); Pledge Protection Act of 2005, S. 1046, 109th Cong. (2005). The House passed its version in July 2006, but the Senate version went nowhere.

13. See Louise Weinberg, The Article III Box: The Power of "Congress" to Attack the "Jurisdiction" of "Federal Courts," 78 TEX. L. REV. 1405, 1407 (2000) (describing the question of jurisdiction stripping as "somewhat unreal" because jurisdiction "is not necessarily the rigorously narrow technical concept that experts on the subject would have it"); see also Ferejohn \& Kramer, supra note 2, at 1034 (" $[\mathrm{I}] \mathrm{t}$ is far more typical for the Court to exercise jurisdiction while applying substantive legal tests that leave political actors free to choose their course of action without any realistic threat of judicial intercession.").

14. See Matthew D. Adler \& Michael C. Dorf, Constitutional Existence Conditions and Judicial Review, 89 VA. L. REV. 1105, 1112-13 (2003) (introducing the idea of a legal rule not existing as law).

15. See id. at 1117-19; see also U.S. CONST. art. I, § 7.

16. Adler \& Dorf, supra note 14, at 1119-20; see also, e.g., Bartnicki v. Vopper, 532 U.S. 514, 555-56 (2001) (rejecting claim for damages under federal statute that could not constitutionally be applied to conduct at issue).

17. See John Harrison, Jurisdiction, Congressional Power, and Constitutional Remedies, 86 GEO. L.J. 2513, 2515 (1998) (describing congressional power to "determine who is entitled to sue whom, for what, and for what remedy").

18. Weinberg, supra note 13, at 1408.

19. Judith Resnik, The Federal Courts and Congress: Additional Sources, Alternative Texts, and Altered Aspirations, 86 GEO. L.J. 2589, 2615 (1998).

20. See generally Resnik, supra note 19, at 2615 (describing statute authorizing prosecution of 
often speak of "jurisdiction" in describing situations in which the rights to be vindicated do not exist as law. Perhaps Louise Weinberg is correct to argue that laws and judicial decisions repealing or limiting substantive rights and causes of action may "loosely but realistically" be called limits on jurisdiction. ${ }^{22}$

I have argued previously that something different occurs when legal rule makers grant judicial subject matter jurisdiction, as opposed to creating or determining the meaning of enforceable substantive rights and the merits of claims on such rights. ${ }^{23}$ It follows that something different occurs when the result of legal rule making is the establishment of a legal rule that strips judicial subject matter jurisdiction, as opposed to a rule that renders enforceable substantive rights and duties nonextant. Even if the results of the distinct rules look similar, they must be kept distinct. Stripping jurisdiction does not, in fact, produce the same results as rendering rights non-extant. The results look similar only if we limit our focus to the size of federal dockets and the number of cases filed in federal courts. A party seeking federal judicial vindication of rights will lose her case, whether for a failure of jurisdiction or a failure of the claim on the merits.

Significant distinctions emerge when we focus on other concerns. The first concern is what remains after narrowing the legal rule. Jurisdiction strips leave enforceable substantive rights in place, but shift enforcement of those rights from federal to state courts. Non-extant rights obviously cannot be enforced in any court. ${ }^{24}$ A second concern involves differences among three fundamental concepts - judicial subject matter jurisdiction, legislative (or prescriptive) jurisdiction, and litigation. Each concept is affected differently by a legal rule that targets jurisdiction as opposed to substantive rights. ${ }^{25}$ The third concern goes to the litigation process, and how legal and factual issues underlying legal rules will be heard and resolved. ${ }^{26}$ Finally, there are differences as to the

particular crime as a "jurisdiction-conferring statute" and the Supreme Court decision striking it down as "arguing against federal jurisdiction for the statute"); Glen Staszewski, Avoiding Absurdity, 81 IND. L.J. 1001, 1014, 1035 (2006) (arguing that recognizing certain "actionable federal constitutional claims would dramatically expand the jurisdiction of federal courts").

21. See United Phosphorus, Ltd. v. Angus Chem. Co., 322 F.3d 942, 951 (7th Cir. 2003) (en banc) ("[L]egislative history shows that jurisdiction stripping is what Congress had in mind in enacting FTAIA.").

22. See Weinberg, supra note 13, at 1407-08; see also Resnik, supra note 2, at 1004 (discussing link between size of federal docket and extent to which Congress regulates under its powers).

23. Howard M. Wasserman, Jurisdiction and Merits, 80 WASH. L. REV. 643, 645 (2005).

24. See Hart, supra note 3, at 1363-64; infra Part IV.A.

25. See infra Parts IV.B.

26. See infra Part IV.C. 
structural and constitutional legitimacy of a legal rule that produces a limit on jurisdiction, as opposed to one that limits or eliminates substantive rights. Whatever the long-standing controversy over Congress's power to jurisdiction-strip, ${ }^{27}$ that controversy does not and should not extend to legal rules producing non-extant rights. ${ }^{28}$

This Article explains these fundamental differences and argues that courts, commentators, and legal rule makers must recognize and respect those differences. The Article proceeds in three steps. First, the Article explains how rights might come to be non-extant - to not exist as law. This concept is founded on Wesley Hohfeld's famous model of legal relations, with a particular focus on legal rules establishing rights, imposing duties, and establishing or maintaining liberties. ${ }^{29}$ Second, the Article discusses eight illustrations of non-extant rights, showing how rights are created and eliminated, and the effect on civil actions brought to enforce those rights. ${ }^{30}$ Third, the Article examines and explains the fundamental distinctions between legal rules that strip judicial subject matter jurisdiction, and legal rules that produce non-extant rights. ${ }^{31}$

\section{Rights, DUTIES, AND LIBERTIES}

To understand the idea of non-extant rights as I use it, we must break down two concepts: (1) legal rights and (2) non-existence as law, or what Matthew Adler and Michael Dorf call "nonlaw." 32

\section{A. Hohfeld's Model of Rights, Duties, and Liberties}

In speaking of "rights," I adopt Wesley Hohfeld's famous model of legal relations. Positive legal rules or norms (whether constitutional, statutory, or common law) are established by an authorized legal rule maker (whether legislative, executive, administrative, or judicial). ${ }^{33}$

27. See supra note 3.

28. See infra Part IV.D.

29. Wesley Newcomb Hohfeld, Some Fundamental Legal Conceptions as Applied in Judicial Reasoning, 23 YALE L.J. 16 (1914). See also Arthur L. Corbin, Jural Relations and Their Classification, 30 YALE L.J. 226 (1921); Steven D. Walt, Corbin on Federal Courts: Legal Positivism and Mid-Century Opposition to Erie (Univ. of Va. Law Sch., Pub. Law \& Legal Theory Working Paper Series, Paper No. 14, 2004), available at http://law.bepress.com/cgi/viewcontent. cgi? article $=1020 \&$ context $=$ uvalwps; infra Part II.

30. See infra Part III.

31. See infra Part IV.

32. Adler \& Dorf, supra note 14 , at 1129.

33. Walt, supra note 29. 
Hohfeld argues that these rules establish a web of eight distinct legal positions, three of which form the focus of the present analysis: (1) rights in the strict sense (also called "claim-rights" ${ }^{34}$ ); (2) duties; and (3) privileges (or liberties). ${ }^{35}$

Claim-rights and duties correlate. A legal rule (established by constitutional, statutory, or common law provision, as written or interpreted) grants to $A$ the right to be treated some way by $B$ or to be free from certain treatment by $B$. If no such positive legal enactment exists, $A$ has no right. The rule of law that grants $A$ 's right necessarily imposes on $B$ a "duty" to act or to refrain from acting in a certain way toward $A$. If such a rule does not exist, $B$ is under no duty to act or refrain from acting. ${ }^{36}$

A claim-right exists if a purported right-holder can invoke legal mechanisms to protect her interests; that is, if what Corbin called the "giant," some sovereign wielding its judicial and executive enforcement processes, will protect the right-holder and punish the duty-holder to help vindicate the right when the latter acts against his obligations. As Corbin explains the framework, a right exists for $A$ when legal rules require government to aid $A$ by controlling or sanctioning $B$ and $B$ 's conduct; if legal rules do not require government to aid $A$ as against $B, A$ has noright. ${ }^{37}$ That is, no right exists as law. It follows that $B$ is under no duty because no duty exists as law.

Rights under the Hohfeldian model contrast with privileges or liberties, which focus on an actor's own conduct. ${ }^{38} B$ has a privilege or liberty when he is entitled to act or not act as he pleases, without interference from the giant. ${ }^{39}$ John Finnis suggests that the distinction between rights and liberties turns on whose conduct is being controlled. The true "claim-right" in $A$ looks to the conduct of $B$ toward $A$, while a

34. See Linda C. McClain, Rights and Irresponsibility, 43 DuKE L.J. 989, 1040 (1994) (arguing that this is the only technically proper use of the word "right").

35. See Hohfeld, supra note 29, at 30; Corbin, supra note 29, at 229; see also Mitchell N. Berman, Coercion Without Baselines: Unconstitutional Conditions in Three Dimensions, 90 GeO. L.J. 1, 32-33 (2001) (describing Hohfeld's model); Walt, supra note 29 (arguing that Hohfeld did not characterize the components of legal rights, but sought to describe the relations between legal positions).

36. See Hohfeld, supra note 29, at 32; see also John FinNis, NATURAL LAW AND NATURAL RIGHTS 200-01 (1980) (describing Hohfeld's model); Corbin, supra note 29, at 229 (same); Walt, supra note 29 (same).

37. See Corbin, supra note 29 , at 229.

38. See Hohfeld, supra note 29, at 33 (emphasizing the "importance of keeping the conception of a right (or claim) and the conception of a privilege quite distinct from each other").

39. See Corbin, supra note 29 , at 229 (stating that if "the giant" will not aid $B$, and $A$ is free from constraint, $A$ has a privilege); Hohfeld, supra note 29 , at 32 (stating that " $X$ has a privilege of entering onto land" is equivalent to " $X$ has no duty to stay off the land"). 
"liberty" in $A$ looks to $A$ 's own acts, omissions, and forbearances toward the world. $^{40}$ Thus, $A$ has a claim-right to receive something from $B$ (positively) or to not be interfered with or dealt with in a certain manner by $B$ (negatively). ${ }^{41}$ On the other hand, $A$ has a liberty to act or not act in some manner as she chooses.

If $B$ has a privilege to act some way, $B$ correlatively bears no duty to refrain from acting; the existence of a duty negates the existence of a liberty and vice versa. ${ }^{42}$ That liberty continues until a different positive legal rule imposes duties on $B$, and correspondingly, grants rights in $A$. Privileges/liberties also cover that part of $B$ 's conduct that is not regulated by a different legal norm. In other words, an extant legal norm may create some right in $A$ and impose some correlative duties on others. But if the right does not extend to $B$ or to $B$ 's particular conduct in some instance, then $\mathrm{B}$ has no duty under that legal rule, meaning $B$ continues to have a liberty to act as he pleases. ${ }^{43}$

Importantly, distinct legal relations can be conjoined, as when $A$ 's liberty to act is enhanced by a claim-right against $B$ that $B$ not interfere with $A$ 's exercise of her liberty. ${ }^{44}$ Thus, as Mitchell Berman suggests, the First Amendment freedom of speech can be understood as $A$ 's liberty to speak conjoined with a claim-right that government $(B)$ not interfere with $A$ 's exercise of that liberty. ${ }^{45}$ And $A$ 's claim-right correlates to the government's duty not to interfere with her exercise of her liberty.

\section{B. Law and Nonlaw}

The second concept, non-existence as law, derives from Adler and Dorf's concept of constitutional "existence conditions." 46 A provision of federal sub-constitutional law (such as a right-creating statute) does not exist as law if some constitutional requirements or pre-conditions are not satisfied. ${ }^{47}$ Existence conditions mark the line "between law and nonlaw," and a purported enactment that does not satisfy those

\footnotetext{
40. FINNIS, supra note 36 , at 200-01.

41. Id.

42. See Hohfeld, supra note 29 , at 32 ("The privilege of entering is the negation of a duty to stay off."); Walt, supra note 29 ("[I]f B has a duty to A to do X, B does not have the privilege (liberty) of doing x. B's privilege to do x is the negative ('opposite') of B's duty to do x.").

43. See Corbin, supra note 29, at 229; Hohfeld, supra note 29, at 32-33.

44. Corbin, supra note 29, at 201.

45. Berman, supra note 35 , at $34 \&$ n. 135 .

46. Adler \& Dorf, supra note 14, at 1107-08 (describing process of identifying what constitutes authoritative utterances from Congress - that is, laws).

47. Id. at $1108,1119-20,1155$.
} 
requirements or conditions is nonlaw. ${ }^{48}$ We can extrapolate that if no provision recognizable as "law" grants a claim-right (and imposes a corresponding duty), the right-duty legal relation also does not exist as law. ${ }^{49}$

Adler and Dorf provide an obvious example. $A$, who suffered injuries on the job, sues $B$, his employer, to enforce rights under the Safe Workplaces Act, a federal statute purporting to create a right to work in a safe environment and providing workers with claims for damages against their employers for work-related injuries. ${ }^{50}$ Unfortunately for the plaintiff, the bill never was enacted into law pursuant to the constitutional requirements of bicameral passage and signature by the President. ${ }^{51}$ It seems obvious that $A$ cannot have a claim-right under a statute that never came into legal being. It seems correlatively obvious that $B$ is not under any duty to act or not toward $A$ in any way imposed by a non-extant provision. It follows that the claim-right in $A$ and duties in $B$ that would have been established by that provision do not exist as law - they are nonlaw.

Whether a right exists as law is a contextual inquiry, not determinable at a too-high level of generality. Existence of a right as law depends on the scope and breadth of the legal rule and whether the right is implicated, or potentially implicated, in particular conduct involving particular actors. A right exists in $A$ as against $B$ only when $A$ falls within the class of the legal norm's right-holders, $B$ falls within the class of duty-bearers, and the conduct is of the kind required or regulated by the norm. ${ }^{52}$ If $A$ 's right and $B$ 's duty are not so broad as to be implicated in the conduct, transaction, or occurrence at issue, the broader right does not exist as law-it is nonlaw. ${ }^{53}$

48. Id. at 1129 .

49. See Bradford R. Clark, Ascertaining the Laws of the Several States: Positivism and Judicial Federalism After Erie, 145 U. PA. L. REV. 1459, 1462 (1997) ("If agents of the state have not adopted rules of decision that provide determinate answers to the questions in the case at bar, then arguably there is simply no law to apply — state or federal — and federal courts should rule against the party who bears the burden of persuasion on the question at issue.").

50. See Adler \& Dorf, supra note 14, at 1117-19. Of course, it is unlikely that anyone would sue under a law that never had been enacted. But this scenario is necessary to illustrate the full scope of the effect of non-extant legal rights.

51. Id. at 1118; see also U.S. CONST. art. I, § 7.

52. See Harrison, supra note 17, at 2520-21 (arguing that the plaintiff's claim depends on allegations and proof that "the defendant's conduct was ... inconsistent with a duty resting on the defendant .... and that the plaintiff is within the category of persons entitled to judicial relief because of the wrongful conduct").

53. See Clark, supra note 49, at 1467 ("[T] he law simply does not apply, by its terms, to a wide variety of human conduct."). 
Existence as law also may be sovereign-specific and rule-makerspecific. The legal relation of right-duty correlative may exist under the laws of one sovereign but not under the laws of another. Constitutional federalism means that some liberties, rights, and duties cannot exist as the law of the federal sovereign through congressional enactment, even if they may exist as the law of a sovereign state. ${ }^{54}$ The problem is not the norm that establishes the right and imposes the duty, but rather the source of the norm. ${ }^{55}$ Similarly, a federal right might exist as federal constitutional law or federal statutory law.

The substantive merits of a legal claim of right focus on who can sue whom over what real-world conduct and for what remedy under applicable law. ${ }^{56}$ In Hohfeldian terms, the focus is who has rights against whom as to what conduct. Success on a claim depends on the plaintiff's showing that the defendant violated some legal right, which means showing that the defendant acted in a way "inconsistent with a duty resting on [him]" in the circumstances at issue. ${ }^{57}$ This is the essence of Charles Clark's definition of a cause of action as "a series of acts or events, which gives rise to one or more legal relations of right-duty enforceable in the courts." 58

$A$ prevails when she invokes the judicial process (i.e., when she calls on the giant) only if she can sue $B$ for the conduct at issue-that is, if a right exists as law in $A$, enforceable against $B$ for this conduct. If no existing legal rule establishes rights and imposes duties on these actors for the acts and events at issue, $A$ loses on her claim. No legal norm exists to be violated by these actors or in these events because the law stopped short of establishing rights and duties.

54. See Resnik, supra note 2, at 1004 (describing arguments that "certain problems ... belong to the states"); see also United States v. Morrison, 529 U.S. 598, 615 (2000) (expressing concern for Congress asserting authority to regulate "areas of traditional state regulation").

55. Resnik, supra note 2, at 980 ("[J]urisdictional arguments can, in a federalist government, also be premised on an objection to the fact of federal-rather than state-enforcement of that norm.").

56. Harrison, supra note 17, at 2515; see James Leonard, Ubi Remedium Ibi Jus, Or, Where There's a Remedy, There's a Right: A Skeptic's Critique of Ex Parte Young, 54 SyRACUSE L. REV. 215, 280 (2004) (arguing that Congress "may therefore choose who is entitled to enforce a claim in court, and equally important, who may not").

57. See Harrison, supra note 17 , at 2520.

58. Charles E. Clark, The Code Cause of Action, 33 YALE L.J. 817, 828 (1924); see also Anthony J. Bellia, Jr., Article III and the Cause of Action, 89 IowA L. REV. 777, 796 (2004) (arguing that Clark viewed a plaintiff as having a cause of action if she was entitled to some remedy on the facts at issue). 


\section{NON-EXTANT RIGHTS: ILLUSTRATIONS}

Under the positivist view, rights are created by a legal rule or norm and a legal rule or norm exists "because it is created by the regular acts of those legislative or judicial officials authorized to do so." 59 Rightcreating legal rules can derive from a number of legal rule makers and a number of legal sources. Rights can be established by the legislative, executive, or judicial branches, acting individually or in concert. They can derive from the Constitution, statutes, or common law. They may be a product of federal law, of state law, or of an interaction between the two.

As to federal statutory rights, the initial rule maker is Congress, which enacts right-creating legislation pursuant to its substantive legislative power to create, decline to create, or limit rights, and to determine "who is entitled to sue whom, for what, and for what remedy." $" 60$ Determinations of the scope and reach of rights created and duties imposed does not end with passage in Congress, since Congress does not and cannot anticipate every real-world factual situation to which a statute will be applied in the future. ${ }^{61}$ A statute also must be interpreted, implemented, and applied to real-world situations by the other branches of government, requiring a seamless process of making policy. ${ }^{62}$ And there similarly is a seamless process of establishing, or not, rights and duties.

Sometimes this role for the other branches is deliberate and explicit. ${ }^{63}$ Many statutes are drafted with the expectation that courts will fill gaps as to the rights created through judicial common law reasoning

59. Walt, supra note 29 ("Its content is fixed by the regular behavior of these officials in creating norms.").

60. Harrison, supra note 17, at 2515. See Leonard, supra note 56, at 280 (describing Congress's substantive authority to legislate within its constitutional ambit, including the power to create or not create causes of action and to choose who may or may not enforce claims in court).

61. See Amanda L. Tyler, Continuity, Coherence, and the Canons, 99 Nw. U. L. REV. 1389, 1404 (2005).

62. See Daniel B. Rodriguez \& Barry R. Weingast, The Paradox of Expansionist Statutory Interpretations, 101 NW. U. L. REV. 1207, 1219 (2007) ("Statutory interpretation represents a critical element in the process by which legislative policy takes shape.”); Donald H. Zeigler, Rights, Rights of Action, and Remedies: An Integrated Approach, 76 WASH. L. REV. 67, 120 (2001) (describing the "drafting, enactment, interpretation, and implementation of legislation as a single, ongoing process").

63. See Lawrence G. Sager, Justice in Plainclothes: A TheOry OF AmericAN CONSTITUTIONAL PRACTICE 32 (2004) (defining "foundational statutes" reflecting "a legislative strategy of generality and incompleteness" and reliance on "the independent normative judgment of the judiciary"); Nicholas Quinn Rosenkranz, Federal Rules of Statutory Interpretation, 115 HARV. L. REV. 2085, 2128-29 (2002) (defining "dynamic interpretive statutes" as "those that hinge on the future actions of others to be given content"). 
and decision making. ${ }^{64}$ Others expressly await action by the President, executive branch officers, or administrative agencies through regulatory rulemaking and enforcement decisions. ${ }^{65}$ Judicial and executive interpretations of a statute become as much a part of the legal rule - and thus the potential source of a right or non-right — as the statutory text. ${ }^{66}$

As to constitutional rules, the common modern understanding is that judicial interpretation and application determines the scope of the liberties and rights created. ${ }^{67}$ And while recent scholarship has sought to de-link the Constitution and the courts, ${ }^{68}$ as a historical matter, no non-

64. See, e.g., Campbell v. Acuff-Rose Music, Inc., 510 U.S. 569, 596 (1994) (Kennedy, J., concurring) ("The common-law method instated by the fair use provision of the copyright statute presumes that rules will emerge from the course of decisions." (citation omitted)); Nat'1 Soc'y of Prof'l Eng'rs v. United States, 435 U.S. 679, 688 (1978) (stating that the legislative history of the Sherman Act "makes it perfectly clear that [Congress] expected the courts to give shape to the statute's broad mandate by drawing on common-law tradition"); see also SAGER, supra note 63, at 31 (arguing that the federal courts "have had to create substantial bodies of law whose origins are the compact and somewhat gnomic congressional utterances").

65. See Gonzales v. Oregon, 546 U.S. 243, 255 (2006) ("Executive actors often must interpret the enactments Congress has charged them with enforcing and implementing."); Chevron U.S.A. Inc. v. Natural Res. Def. Council, Inc., 467 U.S. 837, 843-44 (1984) ("If Congress has explicitly left a gap for the agency to fill, there is an express delegation of authority to the agency to elucidate a specific provision of the statute by regulation."); Gary Lawson \& Christopher D. Moore, The Executive Power of Constitutional Interpretation, 81 IOWA L. REV. 1267, 1286 (1996) ("If Congress passes a statute creating a regulatory scheme and delegating to the President authority to implement it, then the President must interpret the statutory framework in deciding how best to carry the law into effect.").

66. See Alexander v. Sandoval, 532 U.S. 275, 284 (2001) (stating that one cannot separate enforcement of a statute from enforcement of administrative regulations that authoritatively construe the statute itself); Golden State Transit Corp. v. City of Los Angeles, 493 U.S. 103, 112 (1989) ("A rule of law that is the product of judicial interpretation of a vague, ambiguous, or incomplete statutory provision is no less binding than a rule that is based on the plain meaning of a statute.").

67. See City of Boerne v. Flores, 521 U.S. 507, 516 (1997); SAGER, supra note 63, at 70 ("Particularly in its liberty-bearing provisions, the Constitution offers broad structural propositions and moral generalities, and the judiciary has by and large accepted the obligation to fill in these general stipulations with concrete applications, to fashion workable and defensible conceptions of the Constitution's moral concepts."); Larry Alexander \& Frederick Schauer, On Extrajudicial Constitutional Interpretation, 110 HARV. L. REV. 1359, 1377 n.79 (1997) ("Supreme Court decisions provide more clarity than the constitutional text alone.").

68. See, e.g., KRAMER, supra note 5, at 253 (arguing for an understanding of judicial review in which the Supreme Court understands itself as "responsible for interpreting the Constitution according to their best judgment, but with an awareness that there is a higher authority out there with power to overturn their decisions"); SAGER, supra note 63, at 5 (arguing that the Justices disagree about their role in determining constitutional meaning and that "doctrine about the relationship between the Court and other constitutional actors appears to be in the midst of a seismic shift"); Michael Kent Curtis, Judicial Review and Populism, 38 WAKE Forest L. REV. 313, 319 (2003) ("Skepticism about judicial supremacy has its virtues. So does skepticism about a plan to eliminate judicial review."); Edward A. Hartnett, Modest Hope for a Modest Roberts Court: Deference, Facial Challenges, and the Comparative Competence of Courts, 59 SMU L. REV. 1735, 1737 (2006) ("The central question in constitutional adjudication is the degree of deference, if any, that courts give to constitutional interpretation by other governmental actors."); Keith E. Whittington, Extrajudicial Constitutional Interpretation: Three Objections and Responses, 80 N.C. L. REV. 773, 778 (2002) 
judicial actor (Congress or the President) has defied a judicial interpretation or understanding that the Constitution prohibited some law or act. $^{69}$

I turn now to a non-exhaustive series of examples of non-extant rights-legal controversies involving rights that are nonlaw. The examples vary as to the sources and originators of the purported rights, the controlling legal rule maker, the enacting sovereign, and the way non-existence has come about. Three themes unite these disparate illustrations. First, in all cases, the rights asserted, and the duties alleged to have been ignored, do not exist as law. Second, the individuals seeking judicial relief will fail on their claims of right. Third, that failure is for a defect in the merits of the claim of right, not for want of subject matter jurisdiction in the court. It is the result of the non-existence as law of the substantive rights and correlative duties to be judicially enforced with respect to the actors and conduct at issue. ${ }^{70}$ Under existing law, this plaintiff cannot sue this defendant over this conduct. ${ }^{71}$ The only question is whether defeat on the merits will occur at the pleading stage, ${ }^{72}$ at summary judgment, ${ }^{73}$ or at trial on the merits. ${ }^{74}$

(" $[\mathrm{T}]$ he debate over judicial supremacy focuses more squarely on ... who should make the final decision concerning contested [constitutional] interpretations.").

69. Larry Sager argues that conflicts over constitutional meaning between the courts and the political branches rarely, if ever, take the form of "Alpha" disputes, in which the Court determines some government act or practice to be unconstitutional, but other governmental actors disagree and continue those practices. Lawrence G. Sager, Courting Disaster, 73 FordHAM L. REV. 1361, 1364 65 (2005). Rather, they take the form of "Beta" disputes, in which the Court finds some government act or practice to be constitutional, but other governmental actors disagree and discontinue those practices in light of their own constitutional interpretation. Id. Historically, Alpha disagreements produce direct interbranch conflicts and proposals to jurisdiction-strip, $i d$., although recall that such proposals never go anywhere. Id. at 1368. But see Michael Stokes Paulsen, The Most Dangerous Branch: Executive Power to Say What the Law Is, 83 GEO. L.J. 217, 221-22 (1994) (arguing that the President "may decline to execute [statutes] on constitutional grounds, even if those grounds have been rejected by the courts").

70. See Bellia, supra note 58, at 796 (arguing that a plaintiff has a cause of action if the plaintiff is entitled to a general remedy for a violation of a right); Clark, supra note 58, at 828 (defining "successful claim" as a series of acts giving rise to a judicially enforceable legal relation of rightduty); Harrison, supra note 17, at 2521 (arguing that a successful claim requires the plaintiff to plead and prove that the defendant acted inconsistently with a duty resting on him toward the plaintiff).

71. See Harrison, supra note 17 , at 2515.

72. See FED. R. CIV. P. 12(b)(6) (providing for dismissal of claims for failure to state a claim upon which relief can be granted); Bell Atlantic Corp. v. Twombly, 127 S. Ct. 1955, 1964 (2007) (quoting Conley v. Gibson, 355 U.S. 41, 47 (1957)) (stating that a pleading must give the defendant fair notice of the claim and the grounds on which it rests); see also Yazoo County Indus. Dev. Corp. v. Suthoff, 454 U.S. 1157, 1161 (1982) (Rehnquist, J., dissenting from denial of certiorari) (describing Rule 12(b)(6) analysis as looking to whether the complaint presents a claim that can form the basis for legal relief).

73. See FED. R. Civ. P. 56(c) (providing for the rendering of a judgment if "there is no genuine issue as to any material fact" and the party "is entitled to a judgment as a matter of law"); Celotex Corp. v. Catrett, 477 U.S. 317, 322 (1986) (stating that summary judgment is appropriate "against a 


\section{A. Legislating Narrowly Ex Ante}

$A$ sues $B$, a small-town mom-and-pop convenience store with five employees, for employment discrimination under Title VII of the Civil Rights Act of 1964. A performed accounting services as an independent contractor for $B$ and alleges she was terminated because of sex, sexual orientation, and her left-wing political beliefs. $A$ 's claim has several defects. Title VII, as written and interpreted, does not protect independent contractors. ${ }^{75}$ Title VII defines employers subject to the statute as only those entities having fifteen or more employees. ${ }^{76}$ It also does not prohibit discrimination because of sexual orientation ${ }^{77}$ or political affiliation. ${ }^{78}$

No legal right exists in $A$ against $B$ that was violated in the conduct, transaction, or occurrence at issue. $A$, as an independent contractor, has no federal claim-right to be free from discrimination because of sex, sexual orientation, or political affiliation at the hands of a small entity. Conversely, $B$, as a small entity, bears no federal legal duty to refrain

party who fails to make a showing sufficient to establish the existence of an element essential to that party's case, and on which the party will bear the burden of proof at trial"); Anderson v. Liberty Lobby, Inc., 477 U.S. 242, 250-51 (1986) (describing standard as whether "under the governing law, there can be but one reasonable conclusion as to the verdict"); Richard L. Marcus, The Revival of Fact Pleading Under the Federal Rules of Civil Procedure, 86 Colum. L. REV. 433, 484 (1986) (" $[\mathrm{T}]$ he intermediate step of summary judgment exists precisely to enable courts to examine the factual conclusions of the pleader and determine whether they are supported by sufficient evidence to warrant the time and effort of a trial."); Wasserman, supra note 23, at 653-54 (describing use of summary judgment to preview the merits of plaintiff's claims).

74. See Wasserman, supra note 23 , at $654-55,663$ (describing trial on the merits, usually before a jury, as the final stage in the process, where factual disputes are resolved); see also Yazoo County Indus. Dev. Corp., 454 U.S. at 1161 (Rehnquist, J., dissenting from denial of certiorari) (arguing that trial is for the purpose of deciding disputed issues of material fact).

75. See 42 U.S.C. $\S 2000$ e(f) (2000) (“The term 'employee' means an individual employed by an employer....”); Farlow v. Wachovia Bank of N.C., N.A., 259 F.3d 309, 316 (4th Cir. 2001) (affirming grant of summary judgment because plaintiff was an independent contractor, not an employee protected by the statute).

76. 42 U.S.C. $\S 2000$ e(b) (2000). This limitation came about in two steps. Congress set the threshold at twenty-five employees in 1964, then reduced it to fifteen employees (in a merits expansion) in 1972. See Wasserman, supra note 23, at 644 n.2; see also Arbaugh v. Y \& H Corp., 126 S. Ct. 1235, 1238-39 (2006) (holding that quantum-of-employee requirement is an element of the plaintiff's claim); Wasserman, supra note 23, at 703 (making same argument).

77. See Bibby v. Phila. Coca Cola Bottling Co., 260 F.3d 257, 265 (3d Cir. 2001) ("Because the evidence produced by [the plaintiff] — and indeed, his very claim —indicated only that he was being harassed on the basis of sexual orientation, rather than because of his sex, the District Court properly determined that there was no cause of action under Title VII."). But see Andrew Koppelman, Why Discrimination Against Lesbians and Gay Men is Sex Discrimination, 69 N.Y.U. L. REV. 197, 203 (1994) (arguing that stigmatization of gays functions as part of a larger system of social control based on gender).

78. See Eugene Volokh, Same-Sex Marriage and Slippery Slopes, 33 HofStRa L. Rev. 1155, 1188 (2005) (stating that government discrimination based on political affiliation is presumptively unconstitutional, but most states do not prohibit it as to private entities). 
from discriminating against its independent contractors because of their sex, sexual orientation, or political affiliation. $B$ is privileged, or at liberty, to act as it wishes, at least as to federal law.

Although Congress enacted right-creating legislation with Title VII, it drafted the legislation, and thus created rights, more narrowly than the constitutional and political baseline might have allowed. As Oliver Wendell Holmes recognized, "the limits contemplated for the coverage of a statute are as significant a part of its purpose as is its affirmative thrust." "79 Some right to be free from employment discrimination exists as law, but not the broader right that $A$ seeks to enforce on the facts, actors, and events at hand.

The narrowness of existing rights often is a product of the legislative process, whose rules and structures dictate the content of resulting substantive law and the rights created or not created under that law. ${ }^{80}$ Legislative opponents may try to kill or drain the force from a proposed legal rule throughout the legislative process. ${ }^{81}$ The response is bargaining, amendment, and compromise, often by narrowing the rights created - the rights that will exist as law - to minimize objections and to maintain the support of pivotal members of the legislature. ${ }^{82}$

The limitations on the rights existing under Title VII reflect this process. Nothing constitutionally prevented Congress from reaching all entities engaged in interstate commerce, regardless of size, ${ }^{83}$ or from according rights to independent contractors as well as employees. ${ }^{84}$ But legislators included those limitations for a variety of policy reasons - to keep the federal government and federal law away from mom-and-pop

79. Paul M. Bator, The State Courts and Federal Constitutional Litigation, 22 WM. \& MARY L. REV. 605, 633 (1981).

80. See McNollgast, Legislative Intent: The Use of Positive Political Theory in Statutory Interpretation, 57 LAW \& CONTEMP. PROBS. 3, 18 (1984); Nicole L. Guéron, An Idea Whose Time Has Come: A Comparative Procedural History of the Civil Rights Acts of 1960, 1964, and 1991, 104 YALE L.J. 1201, 1201 (1995) (discussing the influence of "procedural mechanisms relied upon by members of Congress to transform a legislative aspiration into a binding law of the United States").

81. See Daniel B. Rodriguez \& Barry R. Weingast, The Positive Political Theory of Legislative History: New Perspectives on the 1964 Civil Rights Act and its Interpretation, 151 U. PA. L. ReV. 1417, 1435 (2003) (arguing that "institutional details of Congress" aid opposition legislators); Glen Staszewski, Rejecting the Myth of Popular Sovereignty and Applying an Agency Model to Direct Democracy, 56 VAND. L. REV. 395, 462 (2003) (arguing that structural filters within the legislative process provide a variety of opportunities to defeat proposed legislation).

82. See Rodriguez \& Weingast, supra note 62, at 1216 (arguing that opposition can be seen "as structuring the processes of legislative bargaining," and that "compromise entails leaving controversial provisions out" or "specifically limiting the impact of the policy in ways that appease pivotal moderates"); Staszewski, supra note 81, at 462.

83. See Wasserman, supra note 23, at 682-83.

84. See 42 U.S.C. $\S 1981$ (2000) (prohibiting discrimination because of race in making and enforcing contracts, including contracts of employment). 
businesses in small communities and to avoid imposing new federal duties on small businesses less able to bear the costs of compliance. ${ }^{85}$ The bill's supporters obtained needed support from moderate congressional Republicans only by narrowing the right in this way. ${ }^{86}$

\section{B. Legislating Narrowly Ex Post}

$A$, a foreign purchaser of vitamin supplements, sues $B$, a United States-based exporter of supplements, for violations of the federal Sherman Antitrust $\mathrm{Act}^{87}$ alleging an anticompetitive effect from $B$ 's foreign, non-domestic sales. ${ }^{88}$ But $A$ 's claim does not satisfy the Foreign Trade Antitrust Improvements Act (FTAIA), which limits the scope of federal antitrust law. ${ }^{89}$ The FTAIA, a 1982 amendment to the Sherman Act, changes the general legal rule so that federal antitrust laws "shall not apply" to trade or commerce with foreign nations. ${ }^{90}$ In other words, $A$ has no federal claim-right to be free from restraints on foreign trade by $B$, and $B$ has no federal duty to refrain from conduct that constitutes such a restraint in purely foreign, non-domestic trade. The right-duty correlative does not exist as federal law.

The statute then excepts from the new rule (in other words, leaves subject to extant United States law) conduct that would otherwise violate federal antitrust law and that has a "direct, substantial, and reasonably foreseeable effect" on domestic (other-than-foreign) trade or commerce. $^{91}$ In the end, a federal right exists as law in $A$ to be free from restraints on foreign trade, with a corresponding duty on $B$ to refrain from such restraints, but only so long as those restraints have some effect on domestic interstate commerce.

85. See 110 CONG. REC. 13,092 (1964) (statement of Sen. Cotton) ("If we desire violence, bitterness, and hatred among the races in this country, I suggest that we put the Federal Government with a club into the livelihood of every small businessman ....”); id. (arguing that Title VII "would lead the Federal Government with all of its power, majesty and bureaucracy into the way of dealing with a small businessman who can ill afford to protect himself'). But see id. (statement of Sen. Morse) ("I know of no reason why we should set small businessmen aside and say, "You can continue discrimination with immunity." ).

86. See id. at 13,088 (statement of Sen. Humphrey) (emphasizing narrow reach of bill that leaves ninety-two percent of employers nationwide uncovered); Rodriguez \& Weingast, supra note 81 , at $1472-73$ (describing the need to make the bill more palatable to pivotal moderate Republicans, leading to amendments ameliorating impact of Title VII on American business).

87. 15 U.S.C.A. $§ 1$ (2004).

88. See F. Hoffmann-La Roche Ltd. v. Empagran S.A., 542 U.S. 155, 158 (2005).

89. 15 U.S.C. $\$ 6$ a (2000).

90. Id.; F. Hoffmann-La Roche, 542 U.S. at 158.

91. 15 U.S.C. $§ 6 \mathrm{a}(\mathrm{B}) ;$ F. Hoffmann-La Roche, 542 U.S. at 159. 
The FTAIA exemplifies a right narrowed into non-existence through ex post legislation. Members of Congress had an opportunity to see how courts interpreted and applied the antitrust act and how the rights and duties worked in the real world. $^{92}$ FTAIA was an intentional congressional response to federal courts adjudicating Sherman Act claims involving wholly foreign anticompetitive conduct and injuries having no domestic impact. ${ }^{93}$ American business, one of the most successful organized interests when it comes to seeking legislative overrides of judicial decisions, ${ }^{94}$ had complained about the lack of clarity as to what international and foreign conduct was permitted or prohibited under these decisions. The amended statute reflected a congressional message "to American exporters (and to firms doing business abroad) that the Sherman Act does not prevent them from entering into business arrangements..., however anticompetitive, as long as those arrangements adversely affect only foreign markets." 95 In other words, Congress clarified the scope of businesses' extant federal duties by narrowing them, in turn broadening their extant federal liberties.

Subsequent narrowing of rights often responds to expansionist judicial interpretations - those that extend statutory rights and duties to require those covered (duty-bound) by the act to do, or refrain from doing, more than anticipated. ${ }^{96}$ A subsequent Congress may have

92. See Ferejohn \& Kramer, supra note 2, at 1020 ("Congress is then implicitly invited to overrule or modify the courts' decisions if Congress decides that they are wrong."); Michael E. Solimine \& James L. Walker, The Next Word: Congressional Response to Supreme Court Statutory Decisions, 65 TemP. L. ReV. 425, 425 (1992) ("Thus, when the United States Supreme Court interprets a federal statute in a manner repugnant to Congress, the latter may respond by legislatively modifying the statute in accordance with its intentions."); Zeigler, supra note 62, at 121 ("[I]f Congress believes that the courts have made a serious error in interpreting a federal statute, Congress can amend it."); see also W. Va. Univ. Hosps., Inc. v. Casey, 499 U.S. 83, 115 (1991), superseded by statute, 42 U.S.C. $\S 1988$ (2000) (Stevens, J., dissenting) ("In the domain of statutory interpretation, Congress is the master. It obviously has the power to correct our mistakes ...."). But see Ferejohn \& Kramer, supra note 2, at 974 n.25 ("Congress is often too busy worrying about new laws to spend its time supervising and revising judicial (mis)interpretations of the old ones."); Tyler, supra note 61, at 1409-10 ("Congress is simply not equipped to react in the normal course to most statutory interpretation decisions and [its] track record suggests that its attention to statutory decisions is highly inconsistent.").

93. See United Phosphorus, Ltd. v. Angus Chem. Co., 322 F.3d 942, 946 (7th Cir. 2003) (en banc) ("[T]here has long been concern about overreaching under our antitrust laws."); see also H.R. REP. No. 97-686, 5-6 (1982), reprinted in 1982 U.S.C.C.A.N. 2487, 2490-91 (1982) (describing inconsistency among lower courts as to quantum of domestic effects necessary for foreign business conduct to be subject to Sherman Act and the business uncertainty created by those inconsistencies).

94. See William N. Eskridge, Jr., Overriding Supreme Court Statutory Interpretation Decisions, 101 YALE L.J. 331, 348 (1991) (finding that twenty-six percent of overrides in the survey were obtained by organized business or labor interests).

95. F. Hoffmann-La Roche, 542 U.S. at 161.

96. See Rodriguez \& Weingast, supra note 62, at 1223-24; Tyler, supra note 61, at 1392 (emphasizing the interpretive importance of the "legislative deal that brokered the statutory 
different policy preferences than the enacting Congress, to which interpreting courts failed to pay sufficient heed, ${ }^{97}$ or it may want to resolve ambiguities left in the original statute in a different direction than judicial decisions interpreting those ambiguities. ${ }^{98}$ The result of the new legal rule is some statutory right-duty correlative existing as law, but it looks different from the right-duty correlative existing as law prior to the amending legislation.

\section{Legislating Narrowly out of Constitutional Concerns}

$A$ sues $B$ and $C$, two real-estate brokerage firms, alleging that the firms (along with many other actors) conspired to fix prices in the sale of New Orleans residential real estate in violation of the federal Sherman Antitrust Act. ${ }^{99} B$ and $C$ argue that their brokerage activities were purely local in nature; thus any conspiracy in which they may have participated was not "in restraint of trade or commerce among the several [s]tates," as required by the statute. ${ }^{100}$ In Hohfeldian terms, $B$ and $C$ argue that, because their conduct did not affect commerce among the states, they have no federal duty to $A$ to refrain from engaging in conspiracies restraining trade, and $A$ has no federal right as to them to be free from such conspiracies.

At first glance, this example is identical to the first two. The rightcreating statute is drafted narrowly, thus no federal statutory right-duty relation exists between $A$ and $B$ on the facts at issue and $A$ has failed to show a violation of rights entitling her to relief on the merits. What is potentially different here is that the factual issue that arguably limits $A$ 's rights - whether $B$ 's and $C$ 's conduct was in restraint of commerce among the several states - is a so-called "jurisdictional element." 101 It is a statutory factual element that functions as a nexus between the legal

language ... as well as any background norms against which the language came into being").

97. See Eskridge, supra note 94, at 390 (arguing that the policy expectations of the current Congress and President may be more important to a court's interpretation than those of the enacting Congress).

98. See Rosenkranz, supra note 63, at 2155 (arguing that statutory ambiguity may allow majorities to form, as members vote for the bill thinking it means different things, and all willing "to take their chances in the courts").

99. 15 U.S.C.A. $§ 1$ (2004); McLain v. Real Estate Bd. of New Orleans, 444 U.S. 232, 234-35 (1980).

100. 15 U.S.C.A. $§ 1 ;$ McLain, 444 U.S. at 235-37. The Supreme Court ultimately rejected the defendants' argument at the pleading stage, holding that the allegations and testimony showed that the defendants' brokerage activities involved an appreciable amount of interstate commerce. Id. at 245.

101. See id. at 242 (describing effect on commerce as a "jurisdictional element of a Sherman Act violation"). 
rule and the specific constitutional power under which Congress enacted that rule and regulated that conduct. ${ }^{102}$

Congress could not legislate under the Commerce Clause against conduct that does not affect commerce in some way, a requirement usually satisfied when the conduct is part of a class of commercial or economic activity. ${ }^{103}$ By including effect on commerce as an element of the statutory claim-right that the plaintiff must plead and prove in every case, Congress ensures that the statute cannot be applied beyond the reach of its substantive constitutional regulatory power. ${ }^{104}$ Any application of the statute necessarily remains within constitutional bounds. The Constitution is, in a sense, "enforced" by narrowing the scope of the statute. ${ }^{105}$

The difference between this and the prior examples is the reason for including the limiting element that renders non-extant the broader right. The limiting element in the Sherman Act narrows the legal rule to ensure the law's constitutionality. The limiting elements in Title VII or the FTAIA narrow the rules as a reflection of discretionary policymaking by the enacting legislative majority. Whether a plaintiff pleads and proves any element of a claim-regardless of why the element has been included in the statute-is a sub-constitutional question of the reach, scope, and application of the statute and the right-duty relation it establishes. ${ }^{106}$ A plaintiff's failure to prove any element— jurisdictional or policy-based-represents a failure of the plaintiff to establish her statutory claim-right or the violation of a correlative duty.

\section{Statutory Override of Common Law Rights}

$A$, an obese young adult suffering from health problems, has been eating fast food every day for ten years. She sues $B$, a major fast-food

102. See Adler \& Dorf, supra note 14, at 1153 ("Congress sometimes chooses to include in its statutes a 'jurisdictional nexus' - that is, a requirement that the government prove that the acts to which a statute is applied in a given case themselves affect interstate commerce.").

103. Gonzales v. Raich, 545 U.S. 1, 17 (2005); see also United States v. Lopez, 514 U.S. 549, 561 (1995), superseded by statute, Omnibus Consolidated Appropriations Act, 1997, Pub. L. No. 102-408, § 101(f) [§ 657], 110 Stat. 3009, 3009-369 to -370 (1996) (codified as amended at 18 U.S.C.A. $§ 922(q)(2)(A)(2005))$; Wasserman, supra note 23, at 679 .

104. See Adler \& Dorf, supra note 14, at 1153 (arguing that whether the jurisdictional nexus is satisfied in particular cases is a question about the statute's scope); Stephen Calkins, The 1990-91 Supreme Court Term and Antitrust: Toward Greater Certainty, 60 ANTITRUST L.J. 603, 632 (1991) (arguing that the Act's "statutory language limits what Congress did prohibit").

105. See Adler \& Dorf, supra note 14, at 1122

106. Id. at 1153 ("Whether the nexus is satisfied in particular circumstances is a distinct question about the statute's scope to be decided only once the statute's existence has been established."). 
chain, in federal court (on diversity jurisdiction) ${ }^{107}$ for state-law fraud, products liability, and consumer protection, claiming that the company used unreasonably unhealthy products in making its food and failed to disclose the harmful ingredients and the negative health effects of the product. She seeks to recover medical expenses related to her obesity. ${ }^{108}$

Suppose that, while the action is pending, Congress passes, and the President signs, the Personal Responsibility in Food Consumption Act of 2005, colloquially, the "Cheeseburger Bill."109 This new law protects the fast food industry from tort claims alleging that the fat content in fast food made it an unsafe product or caused obesity and other health problems. ${ }^{110}$ The bill responded to several tort actions against the fastfood industry and reflected congressional disapproval of how real-world rights had been wielded in courts and congressional desire to limit the scope of those rights. ${ }^{111}$ Suppose $B$ now argues that the new federal law requires dismissal of the pending action upon evidence that $B$ is a manufacturer of a qualified food product and that plaintiff's claim seeks damages relating to obesity and other health problems. ${ }^{112}$

The Cheeseburger Bill would have carved a new federal privilege or liberty for $B$, eliminating what had been $A$ 's extant common law rights and $B$ 's extant common law duties. Some right exists as law, allowing $A$ to be free from $B$ 's negligence and defective products and requiring $B$ to refrain from subjecting $A$ to either. But that right-duty combination no longer exists with respect to the fast food industry's sale of its food products and its alleged causation of obesity and health-related harms. $B$ now has a privilege or liberty, grounded in federal law, to engage in

107. 28 U.S.C. $\S 1332(2000)$.

108. See Pelman v. McDonald's Corp., 396 F.3d 508 (2d Cir. 2005) (reversing dismissal of class action alleging violations of New York Consumer Protection Act and common law negligence); William Haltom \& Michael McCann, Distorting the Law: Politics, Media, and the LITIGATION CRISIS 179-80 (2004) (describing first, voluntarily dismissed, lawsuit against fast food chains for failing to disclose high fat content in food); Richard C. Ausness, Tell Me What You Eat, and I Will Tell You Whom to Sue: Big Problems Ahead for "Big Food"?, 39 GA. L. REV. 839, 84142 (2005) (same).

109. Personal Responsibility in Food Consumption Act of 2005, H.R. 554, 109th Cong. (2005) (as passed by House, Oct. 19, 2005). In fact, this bill never became law. It passed the House of Representatives in October 2005, but was not acted upon in the Senate by the close of the 109th Congress.

110. See H.R. $554 \S \S 3,4(5)(A)$ (prohibiting actions in federal or state court "arising out of, or related to a person's accumulated acts of consumption of a [defined fast food] product and weight gain, obesity, or a health condition"). The bill leaves in place actions for breach of warranty and action in which the plaintiff can show a violation of federal law, along with reliance and causation. Id. $\S 4(5)(\mathrm{B})$.

111. See id. § 2(a)(4) ("[L]awsuits seeking to blame individual food and beverage providers ... are not only legally frivolous and economically damaging, but also harmful to a healthy America.").

112. Id. $\S \S 3(\mathrm{~b}), 4$. 
certain business practices, even if those practices cause obesity and other health harms. ${ }^{113}$

Congress may, by superseding federal legislation, eliminate duties imposed by common law and accord $B$ broader liberty to act without constraint. Common law rules exist "at the sufferance of the legislature," lasting only as long as the legislature approves of the rules and the policy choices reflected in common law. ${ }^{114}$ Legislation in derogation of common law rights is disfavored, as reflected in courts' demand for a clear statement of legislative intent to repeal existing common law rules. ${ }^{115}$ So long as that intent is clear, however, legislation altering or eliminating the controlling common law rule is valid.

Congress's power to preempt state common law through superseding federal statutory law lies at the heart of the Supremacy Clause and Erie. ${ }^{116}$ The result of preemption is that state common law rights do not exist as law; the only extant legal rule is the federal one and whatever rights and duties it grants and imposes, although those rights and duties are narrower under the federal rule. ${ }^{117}$ The most prominent example of such preemption is ERISA, which has been held to completely preempt

113. See id. $\S 4(5)(B)(i)$ (exempting from the bill claims for breach of contract or warranty, if claims are "unrelated to weight gain, obesity, or a health condition associated with ... weight gain and obesity"); id. $\S 4(5)(B)(i i)$ (exempting claims based on knowing violations of federal or state law relating to marketing or advertising, on a showing of reliance and proximate cause).

114. See Christopher J. Peters, Adjudicative Speech and the First Amendment, 51 UCLA L. REV. 705,769 (2004) (describing the "fairly obvious fact that the common law can be overridden by legislation" because "the common law reflects a de facto legislative policy to leave certain fields of the law unplowed by legislation"); see also Landgraf v. USI Film Prods., 511 U.S. 244, 272 (1994) ("In this century, legislation has come to supply the dominant means of legal ordering, and circumspection has given way to greater deference to legislative judgments."); GUIDO CALABRESI, A COMMOn LAW FOR THE AGE OF STAtuTes 5 (1982) ("Courts, limited to honest interpretations of these statutes and committed to legislative supremacy, soon enough began to give them the authority they claimed for themselves.").

115. See, e.g., Norfolk Redevelopment and Hous. Auth. v. Chesapeake \& Potomac Tel. Co., 464 U.S. 30, 35-36 (1983) ("It is a well-established principle of statutory construction that "[t]he common law ... ought not to be deemed repealed, unless the language of a statute be clear and explicit for this purpose." (quoting Fairfax's Devisee v. Hunter's Lessee, 11 U.S. (7 Cranch) 603, 623 (1813)) (alteration in original)); Pierson v. Ray, 386 U.S. 547, 561 (1967) (Douglas, J., dissenting) (discussing canon requiring strict construction of statutes in derogation of common law); John F. Manning, Continuity and the Legislative Design, 79 NOTRE DAME L. REV. 1863, 1873 (2004) (arguing that "the canon . . explicitly directs courts to resolve doubts against changes in the legal status quo").

116. U.S. CONST. art. VI ("This Constitution, and the Laws of the United States which shall be made in Pursuance thereof, . . . shall be the supreme Law of the Land.”); Erie R.R. Co. v. Tompkins, 304 U.S. 64, 78-79 (1938).

117. See Andrew M. Siegel, The Court Against the Courts: Hostility to Litigation as an Organizing Theme in the Rehnquist Court's Jurisprudence, 84 TEX. L. REV. 1097, 1168 (2006) ("A striking number of the most significant preemption cases of the last decade involve claims that federal law expressly or impliedly preempts state common law causes of action ....”). 
state law claims related to the provision of health insurance, making federal law, and the rights-duties it creates, the only extant and applicable law. ${ }^{118}$

Objections to federal statutory derogation of state common law rights boil down to a distrust of legislatures. Legislatures are perceived to be at the mercy of powerful interests who ignore the litigation process and send lobbyists into legislative halls seeking exemption from legal rules that apply to everyone else and from which the less powerful cannot gain similar immunity. ${ }^{119}$ The Supreme Court has recognized that legislative politics "pose[] a risk that it may be tempted to use retroactive legislation as a means of retribution against unpopular groups or individuals."

But that unfairness is overcome by requiring Congress to make its intent clear when it abrogates common law rules, thus abrogating rights and duties. This leaves open the possibility that Congress might be subject to political repercussions should its legislative choice to exempt an industry from ordinary tort liability - to eliminate the industry's extant legal duties and the rights of those harmed by the industry-prove unpopular.

\section{E. Narrowed Constitutional Rights}

$A$, a deputy district attorney, sues $B$, the district attorney, claiming that he was subject to adverse job action for writing numerous letters and memoranda, internally and externally, criticizing the office's investigation and prosecution of a defendant who $A$ believed was innocent. ${ }^{121}$ The Supreme Court rejects $A$ 's First Amendment claim for damages, holding that, because $A$ was a public employee whose official duties involved the type of speech at issue and because $A$ was speaking

118. See, e.g., Aetna Health Inc. v. Davila, 542 U.S. 200 (2004); see also Siegel, supra note 117, at 1168-69 (collecting examples of federal law preempting state law causes of action); $c f$. Catherine Sharkey, Preemption by Preamble: Federal Agencies and the Federalization of Tort Law, 56 DePAul L. Rev. 227, 227-28 (2007) (describing practice of federal agencies using preambles in federal regulations to displace competing or conflicting state common law).

119. See David Kairys, Legislative Usurpation: The Early Practice and Constitutional Repudiation of Legislative Intervention in Adjudication, 73 UMKC L. REV. 945, 946 (2005) (describing concerns for "the resulting race of litigants to the assemblies and unfairness to those who had little or no influence with the legislatures"); $i d$. at 950 (expressing concern for floodgates opening for any industry able to muster legislative support to respond to lawsuits with immunity bills, rather than meeting the substance of the lawsuit).

120. Landgraf v. USI Film Prods., 511 U.S. 244, 266 (1994).

121. Garcetti v. Ceballos, 126 S. Ct. 1951, 1955-56 (2006). 
pursuant to those official duties, his speech was not constitutionally protected from adverse job action. ${ }^{122}$

The Constitution, notably the liberty-bearing provisions of the Bill of Rights and the Reconstruction Amendments, is a prime positive-law source of liberties and claim-rights. ${ }^{123}$ As Mitchell Berman suggests, the First Amendment is best understood as a conjunction of claim-rights and liberties. The First Amendment creates a liberty in $A$ to speak free from constraint and a claim-right against the government that it refrain from interfering with that liberty, in turn imposing a duty on the government to refrain from interfering. ${ }^{124}$

The language of these liberty-bearing provisions is sparse and broad - what exactly does "freedom of speech" or "equal protection of laws" mean? ${ }^{125}$ Determining meaning demands that someone interpret and expound on the bare clauses. It most frequently is the courts, arguably by constitutional design. ${ }^{126}$ In so expounding, courts determine the law that "exists" as the First Amendment, and the scope of the liberties, rights, and duties established by that extant law.

Under the applicable provision of positive law-the First Amendment as interpreted in Garcetti-no liberty-right conjunction exists for $A$. $A$ clearly does not have a claim-right to be free from employment-related government sanction for exercising his liberty to speak. Nor is $B$, acting on behalf of the government, under a duty to tolerate or to not interfere with that speech from its employees. $A$ perhaps has liberty to engage in the expression at issue, in the sense that he is able to speak. But he cannot do so with impunity. If he wishes to maintain good standing at his job, he is under a duty to refrain from such

122. Id. at 1960 .

123. See SAGER, supra note 63, at 3.

124. See FINNIS, supra note 36, at 201; Berman, supra note 35, at 33; supra notes $38-45$ and accompanying text.

125. See SAGER, supra note 63, at 36 (calling these "very general ideas, ideas whose basic thrust and practical extension have been the source of much disagreement"); see also David A. Strauss, Freedom of Speech and the Common-Law Constitution, in ETERNALLY VIGILANT: FREE SPEECH IN THE MODERn ERA 33, 40 (Lee C. Bollinger \& Geoffrey R. Stone eds., 2002) (“[I]t is not obvious what constitutes 'the freedom of speech."'); Staszewski, supra note 20, at 1029 ("While there is obviously no consensus on the meaning of 'the equal protection of the laws,' it has long been recognized that the Equal Protection Clause embodies a principle that similarly situated people should be treated alike and differently situated people should be treated differently." (footnote omitted)).

126. See SAGER, supra note 63, at 71; see also Curtis, supra note 68, at 315-16 (arguing that James Madison emphasized judicial enforcement and guardianship of rights as a way to make the Bill of Rights effective); Larry D. Kramer, Putting the Politics Back into the Political Safeguards of Federalism, 100 CoLuM. L. REV. 215, 288 \& n.278 (2000) (arguing that judicial enforcement was a basis for both Thomas Jefferson and Madison to support a Bill of Rights). 
critical expression - his liberty of expression has been effectively eliminated.

\section{F. Unconstitutional Legislation: Internal Limitations}

$A$, a female student at a state university, sues $B$, a fellow student who she alleges sexually assaulted her, under the federal Violence Against Women Act ("VAWA"). ${ }^{127}$ VAWA prohibits "crimes of violence motivated by gender" and provides a private action for damages and other relief. ${ }^{128}$ In Hohfeldian terms, VAWA creates a federal right in $A$ to be free from private acts of gender-motivated violence and imposes on $B$ a duty to refrain from such acts.

$A$ 's claim fails because the Supreme Court invalidates VAWA as exceeding the internal constraints on congressional lawmaking power. ${ }^{129}$ VAWA exceeds Congress's power under the Commerce Clause ${ }^{130}$ because that power focuses solely on the regulation of "economic activity" and Congress cannot legislate against the aggregate effects of entirely non-economic activity, such as crimes of violence. ${ }^{131}$ VAWA also exceeds Congress's power to enforce the Fourteenth Amendment by "appropriate legislation," 132 running afoul of the "time-honored principle that the Fourteenth Amendment, by its very terms, prohibits only state action."133 By attempting to make private individuals directly liable for

\footnotetext{
127. See United States v. Morrison, 529 U.S. 598, 602-03 (2000).

128. 42 U.S.C. $\$ 13981(b)$, (c) (2000).

129. Morrison, 529 U.S. at 607 (quoting Marbury v. Madison, 5 U.S. (1 Cranch) 137, 176 (1803) ("Every law enacted by Congress must be based on one or more of its powers enumerated in the Constitution. 'The powers of the legislature are defined and limited....'”)); United States v. Lopez, 514 U.S. 549, 592 (1995) (Thomas, J., concurring) (describing the "well-known truth that the new Government would have only the limited and enumerated powers found in the Constitution"), superseded by statute, Omnibus Consolidated Appropriations Act, 1997, Pub. L. No. 102-408, § 101(f) [§ 657], 110 Stat. 3009, 3009-369 to -370 (1996) (codified as amended at 18 U.S.C.A. § 922(q)(2)(A) (2005)); see also THE FEDERALIST No. 52 (James Madison) (discussing limitations on powers of the House of Representatives).

130. U.S. CONST. art. I, § 8, cl. 3 .

131. Morrison, 529 U.S. at 613, 617-18. See also Ruth Colker \& James J. Brudney, Dissing Congress, 100 MicH. L. REv. 80, 115 (2001) ("The Court rewrote the Commerce Clause test .... [by] emphasizing that the economic aspect of the regulated activity was central to holdings in prior decisions .....”). Congress retains a limited power to prohibit employment-related gender-motivated violence, which likely would constitute sexual harassment under Title VII, because details of employee relations are economic and thus within even the narrower Commerce Clause power. See Robert C. Post \& Reva B. Siegel, Equal Protection by Law: Federal Antidiscrimination Legislation After Morrison and Kimel, 110 YALE L.J. 441, 449 (2000).

132. See U.S. CONST. amend. XIV, § 5.

133. Morrison, 529 U.S. at 621 (citing U.S. Const. amend. XIV, § 1); see also Samuel Estreicher \& Margaret H. Lemos, The Section 5 Mystique, Morrison, and the Future of Federal Antidiscrimination Law, 2000 SuP. CT. REV. 109, 151 (2000) ("Rather than acting directly on state
} 
violent criminal acts motivated by gender bias, VAWA goes beyond Congress's power to halt discrimination and misconduct by state officials. ${ }^{134}$

$A$ 's claim fails because the constitutional invalidation of VAWA means that the rights established and duties imposed by that provision do not exist as federal law. This is the paradigm for Adler and Dorf's argument that Congress's enumerated powers state existence conditions for federal legislation-some federal sub-constitutional law exists as federal law only if it falls within the proper scope of federal lawmaking powers. ${ }^{135}$ An invalid law-one that is not consistent with the constitutional rules that limit federal legislation-is nonlaw. ${ }^{136}$ Because VAWA is not constitutionally appropriate given the limits on Congress's legislative power, it cannot exist as federal law and the rights VAWA created cannot exist as federal rights.

Judicial rejection of VAWA's statutory rights was grounded not on constitutional objection to the rights created, but to the fact of federal, rather than state, creation. ${ }^{137}$ The conclusion that these rights do not exist flows from a distinct vision of constitutional structure and which level of

actors such as prosecutors, judges, policemen, and caseworkers, Congress devised a way to help women overcome the effects of state-sponsored bias by suing their attackers themselves."); Post \& Siegel, supra note 131, at 502 ("The Court reaches back to the nineteenth century . . . for the view that it would threaten the 'balance of power between the States and the National Government' for Congress to regulate the conduct of private actors under the Fourteenth Amendment." (quoting Morrison, 529 U.S. at 620)). Valid legislation under $\S 5$ must have "congruence and proportionality" between the constitutional injury to be remedied and the means adopted to that end. Morrison, 529 U.S. at 625-26. A law directed at individuals rather than a State or state actor, the Court seemed to suggest, could not be congruent and proportional. Id.

134. Morrison, 529 U.S. at 627; see also Estreicher \& Lemos, supra note 133, at 157 (arguing that the Court seized on the fact that VAWA's penalties were directed against private individuals as the distinction that took it beyond the limits of $\S 5$ power); Post \& Siegel, supra note 131, at 475 (arguing that Morrison "intimate[s] that even properly 'remedial' Section 5 legislation cannot "prohibit actions by private individuals"'); id. at 483 (arguing that Morrison presents a vision of federal-state relations "which seemingly would prevent Congress from employing Section 5 to regulate the conduct of private parties"). Federal law directly regulating purely private conduct lacked the "congruence and proportionality between the injury to be prevented or remedied and the means adopted to that end" required for a law to constitute legislation "enforcing" (as opposed to redefining) Fourteenth Amendment rights. Morrison, 529 U.S. at 625-26; see also City of Boerne v. Flores, 521 U.S. 507, 520 (1997) (establishing congruence and proportionality standard as test for $\S$ 5 legislation); Colker \& Brudney, supra note 131, at 104.

135. Adler \& Dorf, supra note 14, at 1119-20 (“[A] constitutional provision is an existence condition for that type of law if no proposition can be law of that type unless the provision is satisfied.”); supra Part II.B.

136. See id. at 1129.

137. See Morrison, 529 U.S. at 620 (stating that limitations on the scope of Congress's power under the Fourteenth Amendment "are necessary to prevent the Fourteenth Amendment from obliterating the Framers' carefully crafted balance of power between the States and the National Government"); Resnik, supra note 2, at 1004 (describing arguments that "certain problems ... belong to the states"). 
government should regulate conduct - which level of government should grant rights and impose duties on certain actors and conduct. ${ }^{138}$

But this says nothing about the validity of a legal rule establishing a right in $A$ to be free from private gender-motivated violence and a duty in $B$ to refrain from such violence. The Morrison Court clearly indicated that the same right-duty correlative could exist as law under legal rules established by a different sovereign. ${ }^{139}$

\section{G. Unconstitutional Legislation: External Limitations}

$A$ sues $B$ and $C$ in federal court under the Federal Wiretap Act, which prohibits the intentional disclosure of the contents of wire, oral, or electronic communications where the discloser knows or has reason to know the information was obtained through an unlawful interception. ${ }^{140}$ $A$, an official in a teachers' union involved in a high-profile and contentious labor dispute, had a telephone conversation about the dispute in which, discussing what to do in response to the school board's hardline position, she said that the union was "gonna have to go to their, their homes .... To blow off their front porches, we'll have to do some work on some of those guys."141 The call was intercepted by an unknown person and passed along anonymously to $B$, who in turn passed it to $C$, a radio talk-show host who broadcast the tape. ${ }^{142}$

The Supreme Court rejects, on free-speech grounds, $A$ 's statutory claim against both later-disseminators. The claim is barred by the heightened First Amendment protection accorded publication of truthful information, lawfully obtained, on a matter of public significance, which can be punished only to serve a governmental need of the "highest order." 143 Because neither $B$ nor $C$ had been involved in the initial illegal

138. See Kramer, supra note 126, at 288 ("[T] he Court has apparently made protecting the states from Congress one of its top priorities."'); Post \& Siegel, supra note 131, at 483 (arguing that federalism cases "present an account of our federal system in which there are large stretches of state [and] municipal law free from federal interference").

139. See Morrison, 529 U.S. at 615 (describing domestic violence as an "area[] of traditional state regulation"); infra notes 203-06 and accompanying text.

140. 18 U.S.C. $\$ \S 2511(1)(c), 2520(c)(2)(2000)$.

141. Bartnicki v. Vopper, 532 U.S. 514, 518-19 (2001); Rodney A. Smolla, Information as Contraband: The First Amendment and Liability for Trafficking in Speech, 96 Nw. U. L. REV. 1099, 1113 (2002); Howard M. Wasserman, Bartnicki As Lochner: Some Thoughts on First Amendment Lochnerism, 33 N. KY. L. REV. 421, 440-41 (2006); see also Smolla, supra, at 1144 (describing "Sopranos talk" of getting "dese guys"”).

142. Bartnicki, 532 U.S. at 518-19; Smolla, supra note 141, at 1113; Wasserman, supra note 141 , at 441 .

143. Bartnicki, 532 U.S. at 527-28 (citing Smith v. Daily Mail Publ. Co., 443 U.S. 97, 103 (1979)) ("[I]f a newspaper lawfully obtains truthful information about a matter of public significance 
interception, neither could be subject to damages for subsequently republishing the communication. ${ }^{144}$ While recognizing a strong government interest in protecting the privacy of $A$ and her fellow conversant, those "concerns give way when balanced against the interest in publishing matters of public importance," the truthful information on matters of public concern at the core of the freedom of speech. ${ }^{145}$

In balancing $A$ 's statutory rights and $B$ and $C$ 's First Amendment liberties (or liberty-right conjunctions ${ }^{146}$ ), the latter prevailed. ${ }^{147} \mathrm{We}$ can rephrase this in terms of the web of Hohfeldian legal relations. The federal wiretap statute creates in $A$ a privacy right in her electronic, wire, and oral communications, imposing a corresponding duty on $B$ and $C$ not to intercept or disclose the contents of those communications. But the First Amendment creates in $B$ and $C$ the liberty to publish truthful, lawfully obtained information on a matter of public concern. That liberty translates to their having no duty to refrain from publishing. ${ }^{148}$ That liberty is conjoined with a right in $B$ and $C$ to be free from government interference with that liberty, imposing a correlative duty on the government not to burden $B$ and $C$ 's ability to publish.

By attempting to impose legal sanctions on $B$ and $C$ for exercising that liberty (by granting to $A$ the right to recover civil damages against them), the federal government attempted to impose a duty on $B$ and $C$ toward $A$. In doing so, the federal government breached its own FirstAmendment-imposed duty to $B$ and $C$ not to burden their liberty.

This is another example of constitutional provisions functioning as existence conditions for sub-constitutional law. The right-creating statutory legal rule in the wiretap statute did not exist as law because it was inconsistent with a constitutional rule-here, the external limits

then state officials may not constitutionally punish publication of the information, absent a need ... of the highest order."); id. at 533-34 ("The enforcement of [the statute] implicates the core purposes of the First Amendment because it imposes sanctions on the publication of truthful information of public concern"); see also Wasserman, supra note 141, at 441.

144. See Bartnicki, 532 U.S. at 529-30, 535 (“[A] stranger's illegal conduct does not suffice to remove the First Amendment shield from speech about a matter of public concern."); see also Smolla, supra note 141, at 1116-17 (arguing that the Court "assumed that the subject matter of the intercepted conversation was a matter of public concern."); Wasserman, supra note 141, at 441.

145. See Bartnicki, 532 U.S. at 533-34; Wasserman, supra note 141, at 441-42.

146. See Berman, supra note 35 , at 33; supra notes 38-45 and accompanying text.

147. See Eugene Volokh, Freedom of Speech and Information Privacy: The Troubling Implications of a Right to Stop People from Speaking About You, 52 STAN. L. REV. 1049, 1107 (2000) (" $[T]$ he speech vs. privacy ... tensions are not tensions between constitutional rights on both sides. The Constitution presumptively prohibits government restrictions on speech and perhaps some government revelation of personal information, but it says nothing about interference with speech or revelation of personal information by nongovernmental speakers.").

148. See Walt, supra note 29 ("Likewise, if B has a duty to A to do $\mathrm{x}, \mathrm{B}$ does not have the privilege (liberty) of doing x."). 
imposed on congressional lawmaking power by the First Amendment. ${ }^{149}$ This is consistent with the Framers' understanding of "rights" as "expressing limits on the sorts of laws that Congress could enact." 150 Congress lacks power to enact a law that infringes on First Amendment liberties; thus any purported law that so infringes is nonlaw.

$A$ 's statutory claim against $B$ and $C$, and $B$ and $C$ 's First Amendment defense, illustrate the difficulty of characterizing the freedom of speech within Adler and Dorf's framework of nonlaw. The Bartnicki Court at several points emphasized that its decision did not threaten the constitutional validity of the wiretap law or the ban on unlawfully intercepted communications, but only the propriety of the statute's application to the circumstances at issue-publication of truthful information on a matter of public concern by someone uninvolved in the initial illegal interception. ${ }^{151}$ That sounds like the First Amendment functioning as a condition for proper application of extant law to the instant defendants. ${ }^{152}$ But existence conditions operate by functionally revising a statute and the rights it creates. Individual-liberty-bearing provisions protect against infringing legal rules and judicial protection of those rights entails judicial repeal or revision of constitutionally defective rules. ${ }^{153}$ The First Amendment essentially, if implicitly, redefines the statutory anti-disclosure rule, imposing as a narrowing statutory element the principle that government cannot burden publication of truthful, lawfully obtained information on a matter of public concern. ${ }^{154}$

149. See Adler \& Dorf, supra note 14, at 1120, 1155; Matthew D. Adler, Rights Against Rules: The Moral Structure of American Constitutional Law, 97 Mich. L. REV. 1, 13 (1998) ("Constitutional rights in our own legal world are structured, not as shields around particular actions, but as shields against particular rules.").

150. See Adler \& Dorf, supra note 14, at 1168-69 ("[The Framers] viewed the recitation of rights and the enumeration of powers as mutually reinforcing checks that served the interest of limiting the reach of government.").

151. See Bartnicki v. Vopper, 532 U.S. 514, 524-25 (2001) ("The constitutional question before us concerns the validity of the statutes as applied to the specific facts of these cases .... The only question is whether the application of these statutes in such circumstances violates the First Amendment."); id. at 533 ("[T] be enforced with respect to most violations of the statute without offending the First Amendment.").

152. Existence conditions contrast with "application conditions," which limit the legal force of sub-constitutional law as applied to some facts or circumstances, without invalidating the entire legal provision (that is, removing the provision from status as law). Adler \& Dorf, supra note 14, at 1119. One might view the First Amendment as stating an application condition, with rights functioning simply as "'shields' that deflect weak and medium strength justifications but succumb to very strong ones." Id. at 1161-62. See also id. at 1165 ("The First Amendment provides some (albeit weak) protection to particular speech-acts proscribed under content-neutral laws that may be valid in most circumstances.").

153. Adler \& Dorf, supra note 14, at 1165-66.

154. Bartnicki, 532 U.S. at 527-28; Smith v. Daily Mail Publ'g Co., 443 U.S. 97, 103. The First 
The redrafted statutory ban thus prohibited the knowing disclosure of unlawfully intercepted information, except where that information is truthful, lawfully obtained information on a matter of public concern. Thus stated, $B$ and $C$ were not subject to an extant statutory duty to refrain from publishing the content of the intercepted conversations because no ban on publishing existed or, in light of the First Amendment, constitutionally could exist. Neither could the privacy rights in $A$ purportedly established by that statute exist.

\section{H. Overlapping Rights and Duties from Distinct Legal Rules}

$A$, a woman, works as a truck driver for the City of Chicago Department of Transportation. She was subjected to sexual harassment by $B$, one of her fellow employees. $C$ and $D$, her supervisors, were aware of the harassment but did not take sufficient steps to remedy the situation when she complained and actually took action against her following her complaints. $A$ files suit against the City, $B, C$, and $D$. She asserts a claim of sexual harassment under Title VII against the City, claims of Equal Protection and First Amendment violations against the City and the individual defendants, and several state tort law claims against all defendants. ${ }^{155}$

Here we have one series of related conduct and occurrences involving multiple actors, implicating several distinct right-creating legal rules emanating from distinct sovereigns and sources. Conduct that creates a sexually hostile work environment is discrimination "because of' sex prohibited by Title VII, including by public employers. ${ }^{156}$ Discrimination because of sex by local government and local government officials and employees also violates the Equal Protection

Amendment overrides tort law. and tort law right-duty correlatives, in a similar manner. For example, the "actual malice" standard of New York Times redefines defamation by constitutionally imposing a state-of-mind requirement that the plaintiff must prove in order to prevail on her claim. See New York Times v. Sullivan, 376 U.S. 254, 279-80 (1964) (imposing "a federal rule that prohibits a public official from recovering damages for a defamatory falsehood relating to his official conduct unless he proves that the statement was made with 'actual malice' - that is, with knowledge that it was false or with reckless disregard of whether it was false or not"); Paul A. LeBel, Defamation and the First Amendment: The End of the Affair, 25 WM. \& MARY L. REV. 779, 783 (1984) (arguing that "defamation is the first tort in which, as a federal constitutional matter, wrongful conduct by the defendant has been made an essential element of the plaintiff's prima facie case.").

155. Valentine v. City of Chicago, 452 F.3d 670, 676 (7th Cir. 2006).

156. 42 U.S.C. $\S 2000$ e(a) (2000) (defining persons to include governments and governmental agencies); 42 U.S.C. $\S 2000 \mathrm{e}-2(\mathrm{a})(1)$ (2000) (prohibiting discrimination in employment because of sex); Burlington Indus., Inc. v. Ellerth, 524 U.S. 742, 767 (1998) (Thomas, J., dissenting) (recognizing sexual harassment as prohibited discrimination "because of sex"). 
Clause and is actionable under $\S 1983 .{ }^{157}$ Retaliation against an employee for complaining about sexual harassment violates Title VII, and, if it is a public employee, it also violates the First Amendment and becomes actionable under 42 U.S.C. $§ 1983 .{ }^{158}$ States also have a range of tort rules that could be violated by the actors and conduct at issue.

Substantive rights existing by virtue of different provisions of federal and state law are complementary, rather than exclusive, of one another, with the plaintiff holding the option as to which set of rights, duties, and liberties she wishes to enforce. ${ }^{159}$ At a general level, all these legal rules together provide $A$ with one right- to be free from discrimination and harassment because of sex in her public employment. But distinct legal rules create subtly distinct rights. More importantly, they impose subtly distinct duties on different actors.

For example, only the employer, here the City, bears a Title-VIIimposed duty not to discriminate because of sex; individual employees and supervisors do not. ${ }^{160}$ The contours of the City's duty under Title VII depend on whether the complained-of harassment came from a supervisor or fellow employee, ${ }^{161}$ and whether the harassment resulted in a "tangible employment action," such as termination, or whether the harassment created a hostile environment. ${ }^{162}$

157. Valentine, 452 F.3d at 682 (quoting Bohen v. City of E. Chicago, 799 F.2d 1180, 1185 (7th Cir. 1986)).

158. 42 U.S.C. § 2000e-3(a) (2000). See, e.g., Konits v. Valley Stream Cent. High Sch. Dist., 394 F.3d 121, 125 (2d Cir. 2005) (holding that "any use of state authority to retaliate against those who speak out against discrimination suffered by others, including witnesses or potential witnesses in proceedings addressing discrimination claims, can give rise to a cause of action under . . . the First Amendment."); Perry v. McGinnis, 209 F.3d 597, 608-09 (6th Cir. 2000) (holding that individual's complaint of racial discrimination was speech on a matter of public concern and retaliation for complaint allowed claim of First Amendment violation).

159. See Monroe v. Pape, 365 U.S. 167, 183 (1961) (holding that federal constitutional claim for damages is supplementary to state tort claims for damages from the identical conduct), overruled on other grounds by Monell v. Dept. of Soc. Serv., 436 U.S. 658, 701 (1978).

160. See 42 U.S.C. $\S 2000 \mathrm{e}(\mathrm{b})$ (2000) (defining employer as a person engaged in an industry affecting commerce having a minimum number of employees over a time period); Indest v. Freeman Decorating, Inc., 164 F.3d 258, 262 (5th Cir. 1999) (holding that individual employees cannot be held liable under Title VII); Miller v. Maxwell's Int'l, Inc., 991 F.2d 583, 587-88 (9th Cir. 1993) (same); Julie A. Seaman, Form and (Dys)Function in Sexual Harassment Law: Biology, Culture, and the Spandrels of Title VII, 37 ARIZ. ST. L.J. 321, 427 (2005) (discussing overwhelming weight of authority that only the employer, not individual harassers, are liable under Title VII).

161. An employer is vicariously and strictly liable for harassment by supervisors, but only liable for fellow-employee harassment of which it knew or should have known and about which it did nothing. Seaman, supra note 160 , at $427-29$.

162. The employer is absolutely liable for supervisory discrimination resulting in a tangible employment action, such as termination, but has an affirmative defense in a hostile environment case that the employer acted reasonably to prevent and correct sexually harassing behavior and that the employee unreasonably failed to take advantage of preventive and corrective opportunities. Id. at 428. 
On the other hand, although the city and individual employers all may be liable for Equal Protection violations, their duties under $\S 1983$ and the Constitution have different scopes. The City is duty-bound only to refrain from enacting unconstitutional policies or from knowingly permitting widespread unconstitutional practices that are "so permanent and well-settled as to constitute a "custom or usage" with the force of law." 163 Absent such policy or custom, $A$ holds no claim-right against the City, and the City bears no duty, under this provision of federal law, to $A$. ${ }^{164}$

Individual employees $B, C$, and $D$ all bear individual duties to refrain from intentionally gender-discriminatory conduct. But those duties extend only to conduct committed as state actors or under color of state law - that is, only if $B, C$, and $D$ misused power " "possessed by virtue of state law and made possible only because the $[y]$. . . [were] clothed with the authority of state law." $" 165$ In other words, they are under no enforceable federal duty to refrain from identical gender-discriminatory conduct if they are not state actors at the time they engage in it. ${ }^{166}$

\section{TARGETING JURISDICTION OR TARGETING RIGHTS?}

The reach and scope of federal judicial activity and influence can be constrained by jurisdiction stripping or by the non-existence as law of rights and duties. ${ }^{167}$ Either apparently produces the same effect-fewer successful actions will be brought in federal court to vindicate individual federal rights, arguably depriving courts of the opportunity to perform their central and essential constitutional function. ${ }^{168}$ There is a symbiotic

163. Monell, 436 U.S. at 690-91 (quoting Adickes v. S.H. Kress \& Co., 398 U.S. 144, 167-68 (1970)).

164. See Valentine v. City of Chicago, 452 F.3d 670, 681-82 (7th Cir. 2006) (finding issues of fact requiring trial as to City's potential liability under Title VII); $i d$. at 685 (finding no factual issues as to City's potential liability for some of plaintiff's constitutional claims).

165. Id. at 682 (quoting Honaker v. Smith, 256 F.3d 477, 484-85 (7th Cir. 2001)); see also NCAA v. Tarkanian, 488 U.S. 179, 191 (1988) (quoting United States v. Classic, 313 U.S. 299, 326 (1941)).

166. See Valentine, 452 F.3d at $682-83$ (considering whether individual defendants acted under color of law).

167. See Resnik, supra note 19, at 2613 ("Jurisdictional grants, restrictions, and decisional rules (be they cast in terms of causes of action, removing categories of cases from Article III oversight, ...) are the next template on which to examine court-Congress relations."); supra Part III.

168. See REDISH, supra note 3, at 96 ("[T]oday the primary function of the federal courts is generally thought to be the adjudication and protection of federal rights ...."); Paul Mishkin, The Federal "Question" in the District Courts, 53 COLUM. L. REv. 157, 157 (1953) (arguing that, with the expansion of federal legislation, the exercise of power over federal claims "constitutes one of the major purposes of a full independent system of national trial courts"); Judith Resnik, History, Jurisdiction, and the Federal Courts: Changing Contexts, Selective Memories, and Limited 
relationship between the two. Expansion of substantive rights carries with it an expansion of judicial competence to enforce rights, while contraction of substantive rights means the contraction of judicial competence. ${ }^{169}$

Perhaps the limits on legal rules that render rights non-extant can, as Louise Weinberg suggests, "loosely but realistically" be described as limits on judicial jurisdiction. ${ }^{170}$ Jurisdiction goes beyond the "rigorously narrow technical concept," as does the concept of stripping or limiting jurisdiction. ${ }^{171}$ It makes no difference, the argument goes, whether we speak of limits on substantive rights and causes of action or restrictions on jurisdiction. ${ }^{172}$

This is true if we focus solely on effect on the federal docket. All these rules impose "door-closing and access-limiting" restrictions on federal court decision making. ${ }^{173}$ The party seeking judicial vindication and remedy for a federal legal right loses in either case, removing the case from the docket. ${ }^{174}$ The difference is whether the party loses on the merits or because the court lacks subject matter jurisdiction. ${ }^{175}$

Imaginations, 98 W. VA. L. REV. 171, 226-27 (1995) (describing federal claims as "the very kind of jurisdiction that many today assume to be the quintessential federal moment"); Siegel, supra note 117, at 1123 (criticizing Rehnquist Court decisions that "ignore[] or downplay[] . . . the historic role of the federal courts in insuring that remedial schemes are sufficient to protect federal rights"); see also Sager, supra note 3, at 43 ("[T]he jurisdiction of the Supreme Court to review state conduct cannot be reduced to a point where effective federal judicial supervision of that conduct is no longer available."); Hart, supra note 3, at 1365 ("[E]xceptions must not be such as will destroy the essential role of the Supreme Court in the constitutional plan.").

169. See Weinberg, supra note 13, at 1409-10 (arguing that the dockets of the federal courts "swell whenever Congress enacts yet another new law giving rise to new federal rights").

170. Id. at $1407-08$.

171. Id.

172. See Resnik, supra note 19, at 2593, 2613; Resnik, supra note 2, at 979 (describing objections to new causes of action through arguments about special character and import of federal courts); Weinberg, supra note 13, at 1407-08; see also Ferejohn \& Kramer, supra note 2, at 1034 (" $[\mathrm{I}] \mathrm{t}$ is far more typical for the Court to exercise jurisdiction while applying substantive legal tests that leave political actors free to choose their course of action without any realistic threat of judicial intercession."); Siegel, supra note 117, at 1115 (discussing Rehnquist Court's hostility to litigation that "comes across as an overt inclination to close the courts to particular kinds of claims or claimants, at other times as skepticism about doctrinal innovations that might have the immediate or second-order consequence of facilitating litigation").

173. Weinberg, supra note 13, at 1408; see also Resnik, supra note 19, at 2593 (arguing that limitations on decision making by Article III judges come, in part, from "cases not often characterized as 'about' Article III but denominated as 'about' congressional commerce clause powers").

174. See Clark, supra note 49, at 1462 (arguing that if there is no law to apply, "federal courts should rule against the party who bears the burden of persuasion on the question at issue").

175. Important procedural consequences follow from the difference between a loss on the merits and a loss for lack of subject matter jurisdiction. See Arbaugh v. Y \& H Corp., 546 U.S. 500, 50607 (2006) (describing differences between lack of subject matter jurisdiction and failure to state a claim on the merits); Howard M. Wasserman, Jurisdiction, Merits, and Substantiality, 42 TULSA L. 
But differences emerge when focus shifts to other considerations. I argued previously that something fundamentally different occursconceptually, analytically, procedurally, and politically-when legal rule makers create enforceable substantive rights (and impose enforceable substantive duties) as opposed to granting subject matter jurisdiction. ${ }^{176}$ It follows that something fundamentally different occurs when the result of the process of legal rule making is the non-existence of enforceable rights as opposed to the limitation or elimination of subject matter jurisdiction.

We must recognize and distinguish situations in which Congress has targeted the jurisdiction of the courts from situations in which legal rule makers have targeted the scope of extant Hohfeldian claim-rights, duties, and liberties. Differences between jurisdiction and merits become clear when viewed through the lens of differences between true jurisdiction strips and claims asserted on non-extant rights.

\section{A. Remainders}

The first difference is what remains in the wake of a legal rule that strips jurisdiction as opposed to a rule that renders rights non-extant. The distinction focuses on those real-world actors to whom rights and privileges have been given and on whom duties have been imposed.

In the wake of a true jurisdiction strip, federal rights remain in place and enforceable. But they are not enforceable in federal court. For example, even if federal courts are stripped of the power to adjudicate challenges to government acknowledgement of God as the sovereign source of law, liberty, or government, ${ }^{177}$ there nevertheless remains a right, grounded in the First Amendment's Establishment Clause, not to be confronted or coerced by government displays or acts that have the purpose or effect of endorsing religion or coercing participation in religious activities. ${ }^{178}$ And there remains in place a governmental duty

REV. 579, 596-99 (2007) (describing the formalist and procedural distinctions between analysis of jurisdiction and analysis of merits).

176. Wasserman, supra note 23 , at $669-70$.

177. See Constitution Restoration Act of 2005, S. 520, 109th Cong. (2005).

178. See Lee v. Weisman, 505 U.S. 577, 592 (1992) ("A state-created orthodoxy puts at grave risk that freedom of belief and conscience which are the sole assurance that religious faith is real, not imposed."); id. (discussing concern for "subtle coercive pressure" of government-sponsored religious activities); County of Allegheny v. ACLU of Greater Pittsburgh, 492 U.S. 573, 601 (1989) ("[B]y prohibiting government endorsement of religion, the Establishment Clause prohibits precisely what occurred here: the government's lending its support to the communication of a religious organization's religious message."); see also McCreary County v. ACLU, 545 U.S. 844, 882-83 (2005) (holding that display of Ten Commandments in public courthouse violated Establishment 
not to erect displays or conduct ceremonies coercing or endorsing religion. The jurisdiction strip only incidentally affects holders of federal rights by depriving them of one forum (albeit the historically best forum) in which to vindicate those rights. Other forums, namely state courts, remain. ${ }^{179}$

By contrast, if no real-world right exists as law, then no federal realworld duty exists as law to be enforced in any court, federal or state. All that remains is a power in $B$ to act against $A$ (and others), immune from restraint or obligation to "the giant." Such rules do not shift cases among judicial forums; they eliminate cases (or at least successful cases) altogether. ${ }^{180}$

The result of the Morrison Court striking down VAWA is that there is (and can be) no federal right to be free from private, non-employmentrelated gender-motivated violence and no federal duty to refrain from such violence. ${ }^{181}$ The result of Title VII's limitations on the definition of employer means there is no federal right to be free from race or sex discrimination in employment if one works for a company with fewer than fifteen employees; and, conversely, no federal duty to refrain from such discrimination is imposed on a company with fewer than fifteen employees. ${ }^{182}$ The result of the First-Amendment analysis in Garcetti is that a public employee does not enjoy liberty to engage in certain expression with job-related impunity. ${ }^{183}$ These right-duty correlatives do not exist, and thus are not enforceable in any court, federal or state.

Clause); Santa Fe Indep. Sch. Dist. v. Doe, 530 U.S. 290 (2000) (striking down school district program of student-led prayer prior to football games); County of Allegheny, 492 U.S. at 601-02 (holding that display of crèche in county building violated Establishment Clause).

179. See Bator, supra note 79, at 628-29 ("The state courts do constitute an ultimate protection against tyrannous government."); Gunther, supra note 1, at 920 ("Congress merely relies on the state courts to enforce federal rights, part of their traditional, originally contemplated role ...."); Hart, supra note 3, at 1364 (arguing that the "consequence is merely to force proceedings to be brought, if at all, in a state court"); Sager, supra note 3, at 42 (arguing that jurisdiction stripping "in the end offers Congress only the mean solace of pushing cases from one judicial bailiwick into another"); Weinberg, supra note 13, at 1415 ("[A]s long as there is access to state courts for enforcement of federal law, the question [of jurisdiction stripping] cannot have much bite."); see also Pfander, supra note 12, at 237 (arguing that jurisdiction-stripping bills confer exclusive original jurisdiction on state courts). But see Gerhardt, supra note 11, at 1282-83 (arguing that jurisdiction-stripping proposals will "allow state courts to completely circumvent, narrow, and effectively overrule what the Court has already said about these or similar claims").

180. See Siegel, supra note 117, at 1175 (arguing that only stripping a party of a right to bring a civil action can ensure that a plaintiff will be unable to find a judicial forum favorable to her claim).

181. See supra Part III.F.

182. See supra Part III.A

183. See supra Part III.E. 


\section{B. Jurisdiction of Whom to Do What}

Difficulty in separating legal rules stripping jurisdiction from those diminishing substantive rights stems, in part, from confusion over the meaning of jurisdiction, that word of "many, too many meanings." 184 Evan Tsen Lee defines jurisdiction as "something like legitimate authority." "185 But any governmental body, not only courts, can wield "legitimate authority." The question is legitimate authority in whom to do what?

This raises the critical distinction between judicial jurisdiction of the federal courts and legislative (or prescriptive) jurisdiction of Congress. The latter is the authority to legislate, to regulate particular real-world actors and conduct by prescribing prospective legal rules of general applicability. ${ }^{186}$ The former is the raw adjudicative power of the courts, the authority to hear, decide, and resolve legal and factual disputes arising under those legal rules. ${ }^{187}$ It is, in Lawrence Sager's words, "the motive force of a court, the root power to adjudicate a specified set of controversies." " ${ }^{188}$ In Hohfeldian terms, legislative jurisdiction is power to prescribe legal rules creating rights and imposing duties, while judicial jurisdiction is power to provide the adjudicative forum to resolve allegations that those duties have been ignored and rights violated.

Confusion between jurisdictional types leads to inappropriate distinctions between the effect and treatment of jurisdictional and policybased statutory elements. In Arbaugh v. $Y \& H$ Corp., the Court was correct in insisting that statutory elements go to substantive merits unless

184. Arbaugh v. Y \& H Corp., 546 U.S. 500, 510 (2006).

185. Evan Tsen Lee, The Dubious Concept of Jurisdiction, 54 HASTINGS L.J. 1613, 1620 (2003).

186. See Hartford Fire Ins. Co. v. California, 509 U.S. 764, 813 (1993) (Scalia, J., dissenting) (arguing that "legislative jurisdiction' .... refers to 'the authority of a state to make its law applicable to persons or activities") (citing RESTATEMENT (THIRD) OF THE FOREIGN RELATIONS LAW OF THE United States 231 (1987)); United Phosphorus Ltd. v. Angus Chem. Co., 322 F.3d 942, 953 (7th Cir. 2003) (en banc) (Wood, J., dissenting) (describing "jurisdiction to prescribe a rule of law"); Kulick v. Pocono Downs Racing Ass'n, 816 F.2d 895, 898 (3d Cir. 1987) (describing Congress's "constitutional authority to act"); Leonard, supra note 56, at 280 ("Congress' substantive authority to legislate within its constitutional ambit entails the power to create or to refuse to create causes of action.").

187. See Sosa v. Alvarez-Machain, 542 U.S. 692, 714 (2004) (defining jurisdiction as "the power of the courts to entertain cases concerned with a certain subject"); Davis v. Passman, 442 U.S. 228, 239 n.18 (1979) (defining jurisdiction as "a question of whether a federal court has the power, under the Constitution or laws of the United States, to hear a case"); Hagans v. Lavine, 415 U.S. 528,538 (1974) (defining jurisdiction as "essentially the authority conferred by Congress to decide a given type of case one way or the other"); Lee, supra note 185, at 1620 (defining jurisdiction as "legitimate authority").

188. Sager, supra note 3, at 22 . 
Congress provides otherwise. ${ }^{189}$ But the Court failed to address the continued validity of prior cases in which it at least was suggested that the failure of a jurisdictional element (such as agreement in restraint of trade or commerce among the several states under antitrust laws ${ }^{190}$ ) might affect judicial jurisdiction despite the absence of a clear statement designating the element as jurisdictional. ${ }^{191}$ Properly understood, jurisdictional elements simply designate the link between what conduct Congress did regulate and what conduct Congress could regulate, keeping the former within the bounds of the latter; that has everything to do with prescriptive jurisdiction and nothing to do with judicial jurisdiction. ${ }^{192}$

As I have argued previously, the effects of non-satisfaction of any element are identical: the plaintiff has failed to prove a breach of the rights created and duties imposed by a statutory rule and the plaintiff's claim of right fails on its merits. ${ }^{193}$ That is so whether the narrowness of the right results from a limiting jurisdictional element, ${ }^{194}$ a limiting policy-based element included in the original enactment, ${ }^{195}$ or a limiting policy-based element added in subsequent legislation responding to expansive judicial interpretation and application of the original statutory rule. ${ }^{196}$

The 1995 Long Range Plan for the Federal Courts demonstrates the problematic conflation of jurisdictional types. ${ }^{197}$ The report describes a

189. See Arbaugh, 546 U.S. at 516 ("[W]hen Congress does not rank a statutory limitation on coverage as jurisdictional, courts should treat the restriction as nonjurisdictional in character."); Wasserman, supra note 175, at 582 (arguing that, after Arbaugh, statutory factual issues go to the merits unless Congress explicitly provides otherwise); Wasserman, supra note 23, at 693 ("The elements of the underlying statutory claim... provide the exclusive focus of... [the] merits analysis.").

190. 15 U.S.C.A. $\$ 1$ (2004); McLain v. Real Estate Bd. of New Orleans, Inc., 444 U.S. 232, 242 (1980) (labeling effect on commerce as a jurisdictional element); Calkins, supra note 104, at 632 (arguing that the "statutory language limits what Congress did prohibit").

191. See McLain, 444 U.S. at 246 ("What was submitted shows a sufficient basis for satisfying the [Sherman] Act's jurisdictional requirements under the effect-on-commerce theory . . .."); Hosp. Bldg. Co. v. Trs. of Rex Hosp., 425 U.S. 738, 742 n.1 (1976) (“[O]ur analysis in this case would be no different if we were to regard the District Court's action as having been a dismissal for want of subject-matter jurisdiction under Rule 12(b)(1). In either event, the critical inquiry is into the adequacy of the nexus between respondents' conduct and interstate commerce that is alleged in the complaint."); supra Part III.C.

192. See Calkins, supra note 104, at 632 (arguing that concerns for what Congress did regulate or could regulate do not limit the power of federal courts to hear cases properly initiated); supra notes 103-06 and accompanying text.

193. See Wasserman, supra note 23, at 687.

194. See supra Part III.C.

195. See supra Part III.A.

196. See supra Part III.B

197. Judicial Conference of the United States, Long RANGe Plan for the Federal 
dispute between "those who favor increased 'federalization' of the law against those who favor limiting federal court jurisdiction." 198 But increasing "federalization" of the law is not the antithesis of limiting jurisdiction. Federalizing the law sounds in an expansion of substantive law, entailing increased exercise of Congress's prescriptive jurisdiction imposing new federal statutory rights and duties. That may, but need not, affect the judicial jurisdiction of the courts.

Commentators such as Judith Resnik often discuss the existence or non-existence of federal legal norms, and thus of federal rights and duties, as "granting or repealing federal jurisdiction." 199 That is accurate as a discussion of federal prescriptive jurisdiction - the constitutional power (and wisdom) of Congress enacting rights-creating legislation and enforcing particular norms as matters of federal law. ${ }^{200}$ A more precise description is that Congress pulls issues "into the federal net" by wielding its authority to make "an array of issues "federal" and to "regulate a broad range of activities and behaviors."201

But that debate is about how much real-world conduct Congress can or should regulate; it is only incidentally about increasing or decreasing the federal courts' dockets. ${ }^{202}$ Morrison, for example, ultimately turned on the Court's understanding that the conduct at issue-private, nonemployment-related acts of gender-motivated violence-is to be regulated by local, rather than federal, rule makers. ${ }^{203}$ Congress cannot regulate (that is, assert prescriptive jurisdiction over) some conduct, the argument goes, because "certain problems should not become federal cases but belong to the states." 204 But the Morrison Court did not reject the basic idea of a right-duty correlative with respect to private gendermotivated violence. Rather, state and local government, not the United States, is the appropriate sovereign to establish the right-creating legal rule-whether through a VAWA-like right to be free from gender-

COURTS, reprinted in 166 F.R.D. 49 (1995) [hereinafter LONG RANGE PLAN].

198. Id. at 66; see also Resnik, supra note 19, at 2619-20 (describing the Plan's criticism of Congress and calls for "restraint" in creating new federal causes of action on issues previously resolved in state courts).

199. Resnik, supra note 2, at 979.

200. Id. at 979-80; see also Resnik, supra note 19, at 2620; supra notes $186-92$ and accompanying text.

201. Resnik, supra note 2, at 1004-06 \& n.323; id. at 980 ("Federal jurisdictional discussions thus became a means by which to enact conflict about legal rules.").

202. See id. at 1004 .

203. United States v. Morrison, 529 U.S. 598, 615 (2000); see also United States v. Lopez, 514 U.S. 549, 561 (1995), superseded by statute, Omnibus Consolidated Appropriations Act, 1997, Pub. L. No. 102-408, § 101(f) [§ 657], 110 Stat. 3009, 3009-369 to -370 (1996) (codified as amended at 18 U.S.C.A. $\S 922(q)(2)(A)(2005))$.

204. Resnik, supra note 2, at 1004 (discussing LONG RANGE PLAN). 
motivated violence, ${ }^{205}$ or through a similar right via common law rules of assault, battery, false imprisonment, and intentional infliction of emotional distress. ${ }^{206}$

Importantly, claims on these state-created rights actually may fall within the adjudicative jurisdiction of the federal courts. A plaintiff could bring her state-law claim in federal court if, for example, it falls within the court's diversity jurisdiction, where victim and attacker are from different states and the action is for more than $\$ 75,000{ }^{207}$ The federal court would apply state law to determine the rights and duties in that case. ${ }^{208}$

But that drives home the point: the issue is which sovereign (federal or state) asserts the legitimate authority to prescribe applicable substantive rules creating rights and imposing duties - in other words, who can or will assert prescriptive jurisdiction. The issue is not whether federal courts can assert judicial jurisdiction to provide the adjudicative forum, resolve legal and factual issues, and vindicate rights.

This division of prescriptive jurisdiction occurs between sovereigns. It also may occur between different rule makers within a single sovereign. Willingness of one rule maker to enact a right-creating rule affects the need for, or willingness of, a different rule maker to do the same. For example, in the late 1950s and early 1960s, the civil rights movement sought to use the courts to establish a right of access to privately owned places of public accommodation through the Fourteenth Amendment. ${ }^{209}$ But that right could exist only if the Court relaxed the state-action requirement of the Fourteenth Amendment and $\S 1983 .{ }^{210}$ By 1963, the Court had reached an impasse in its effort to establish a single standard for when and how private conduct might constitute state action for purposes of constitutional duty. ${ }^{211}$ Unable to fully establish the

205. See, e.g., New York, NY, Admin. COde OF THE City of New York tit. 8, ch. 9 (2000).

206. See Ellen M. Bublick, Tort Suits Filed by Rape and Sexual Assault Victims in Civil Courts: Lessons for Courts, Classrooms and Constituencies, 59 SMU L. REV. 55, 58-59, 71-72 (2006) (describing increasing numbers of state tort claims stemming from sexual assaults, using a wide range of common law and statutory causes of action). Of course, the right-duty correlative under common law assault or battery is not identical to the right-duty correlative under VAWA.

207. See 28 U.S.C. § 1332(a) (2000) (granting district courts original jurisdiction over civil actions, inter alia, between citizens of different states where the amount in controversy exceeds $\$ 75,000)$.

208. See Erie R.R. Co. v. Tompkins, 304 U.S. 64, 78 (1938).

209. See Post \& Siegel, supra note 131, at 488 (arguing that the federal courts became clogged with thousands of suits by protesters challenging Jim Crow laws).

210. Id. at 497-98 ("Throughout the 1960s the Court was under intense pressure to relax the state action requirement for judicial enforcement of Section 1 [of the Fourteenth Amendment].").

211. See Joel K. Goldstein, Constitutional Dialogue and the Civil Rights Act of 1964, 49 ST. LOUIS U. L.J. 1095, 1100-01 (2005) (describing views of Justices as to reach of Fourteenth 
right to equality through the courts and the Constitution, civil-rights advocates turned to a different rule maker (Congress) and a different source of rights (statutory law). ${ }^{212}$ But all remain right-duty correlatives established by the federal sovereign. ${ }^{213}$

In turn, as Robert Post and Reva Siegel argue, the enactment of civilrights legislation prohibiting discrimination by non-state actors ${ }^{214}$ reduced the pressure on the Court to liberalize the state-action requirement or to broaden constitutionally based rights and duties. ${ }^{215}$ Because there was an alternative source of extant positive federal law establishing equality rights, the Court could (and did) narrow the scope of extant constitutional rights, "secure in the belief that congressional legislation would provide relatively full implementation of antidiscrimination norms."

\section{Litigation or Jurisdiction}

At the heart of the separation between judicial jurisdiction and substantive rights is a distinction between jurisdiction and litigation. That distinction lies at the heart of the separation between legal rules that strip jurisdiction and those that render non-extant substantive rights and duties.

Jurisdiction is a court's root power to adjudicate legal and factual disputes brought before it by parties. ${ }^{217}$ Litigation is the broad process of judicial dispute resolution. It includes within it "decision[s] by particular individuals or groups to resolve problems and [to] seek redress through formal application to the courts, [as well as a] complex of individuals, institutions, and practices through which such disputes are [resolved]. ${ }^{218}$ Andrew Siegel argues that litigation is a social institution-a "complex of cultural attitudes about problem solving, institutional arrangements,

Amendment).

212. Id. at 1097 (arguing that "the political branches commenced a 'constitutional dialogue' that resulted in a political resolution" of the question (footnote omitted)); see Post \& Siegel, supra note 131 , at 498 \& n.267.

213. The result is that an individual's rights may be protected or not protected by a combination of federal right-creating provisions, constitutional and statutory. See supra Part III.H.

214. That is, creating a right to be free from discrimination by certain private actors and a duty in such private actors not to discriminate.

215. See Post \& Siegel, supra note 131, at 517-18.

216. Id. at 518. See, e.g., Washington v. Davis, 426 U.S. 229, 239 (1976) (holding that Fourteenth Amendment prohibits only intentional discrimination); Jackson v. Metro. Edison Co., 419 U.S. 345, 350 (1974) (holding that privately owned and operated utility company, although subject to pervasive state regulation, was not a state actor bound by the Fourteenth Amendment).

217. See supra notes $187-88$ and accompanying text.

218. Siegel, supra note 117 , at 1114 . 
doctrinal rules, and professional roles that nourish our particular judicially focused dispute-resolution system."219

Litigation and jurisdiction are not mutually exclusive and there certainly is overlap. Jurisdictional rules are part of the practices through which disputes are resolved. Stripping federal courts of jurisdiction is one way to control and limit litigation, at least in federal courts. Diminishing existing real-world rights, liberties, and duties is another way to reduce the amount of federal litigation (or, from the plaintiff's standpoint at least, the amount of successful federal litigation). But a change, in either direction, in the amount of litigation does not necessarily equate to a change in the amount of federal jurisdiction, in the sense of the quantum of raw adjudicative authority.

For purposes of $\S 1331$ 's grant of general federal question jurisdiction, the term "arising under" federal law has come to mean one of two things: (1) the plaintiff's claim of right was created by or founded directly on or made possible by federal law, where federal law creates a cause of action and substantive right to a remedy for violation of that national rule ${ }^{220}$ or (2) the outcome of the case turns on the construction or application of a provision of federal constitutional or statutory law, with one construction entitling the plaintiff to relief and the other depriving her of that relief. ${ }^{221}$ Either standard is satisfied in the main run of cases seeking to recover on rights existing under a federal constitutional or statutory provision, such as Title VII - a claim of federally created right asserted in a federally created cause of action over which Congress intended to grant federal jurisdiction. ${ }^{222}$

219. Id.

220. See Wasserman, supra note 23, at 694-97 (compiling various definitions offered by courts and commentators); see also, e.g., Jones v. R.R. Donnelley \& Sons Co., 541 U.S. 369, 377 (2004) (describing requirement that claim be "made possible" by an applicable federal statute); Smith v. Kansas City Title \& Trust Co., 255 U.S. 180, 214 (1921) (Holmes, J., dissenting) ("[A] suit cannot be said to arise under any other law than that which creates the cause of action."); Am. Well Works Co. v. Layne \& Bowler Co., 241 U.S. 257, 260 (1916) (Holmes, J.) (arguing that a suit arises under federal law where that law "creates the cause of action").

221. See, e.g., Steel Co. v. Citizens for a Better Env’t 523 U.S. 83, 89 (1998) (stating that a claim arises under federal law where the plaintiff wins under one conceivable construction of federal law and loses under another); Gully v. First Nat'l Bank, 299 U.S. 109, 112 (1936) (Cardozo, J.) ("The right or immunity must be such that it will be supported if the Constitution or laws of the United States are given one construction or effect, and defeated if they receive another."); REDISH, supra note 3, at 105 (arguing that a case arises under federal law if "the outcome of the case may turn on construction of federal law"); Donald L. Doernberg, There's No Reason for It; It's Just Our Policy: Why the Well-Pleaded Complaint Rule Sabotages the Purposes of Federal Question Jurisdiction, 38 HASTINGS L.J. 597, 656-57 (1987) (emphasizing the presence of federal issues "whose decision one way will necessarily cause a result in the case, and whose decision the other way will tend to prevent it").

222. See REDISH, supra note 3, at 96 ("As a practical matter, the overwhelming majority of 
This jurisdictional structure is significant in that once a legal rule maker creates a federal right, a right-holder can vindicate that right in federal court against the actor who breached his duties without Congress having to do or say anything further about judicial jurisdiction. ${ }^{223}$ The court possesses root power to hear and resolve substantive legal and factual issues brought before it; it merely awaits the bringing of those claims by right-holders. That power remains unless and until Congress affirmatively divests courts of it.

That quantum of adjudicative authority is unchanged by the nonexistence as law of substantive federal rights. Non-existence of rights means fewer real-world actors and less real-world conduct are subject to federal legal protection or federal legal constraint. There are fewer federal right-holders, fewer federal duty-bound actors, and less conduct subject to federal legal constraint, suit, and liability. But courts remain open for business, empowered to hear and resolve whatever claim-rights do exist as federal law and are brought before them. ${ }^{224}$

General federal question jurisdiction is akin to potential energy-it is power, waiting to be released when acted upon by an outside force. For the federal courts, that outside force is parties bringing civil actions alleging injury and seeking relief under a right-creating federal legal norm. To the extent fewer parties do so because of reductions in the quantum of enforceable federal right-creating law, the courts may face a reduced caseload. Or courts may simply enter fewer judgments on the merits in favor of plaintiffs, as claims of right fail because no enforceable legal right exists. But courts have not lost any of their root power to hear and resolve legal and factual issues. They merely are exercising that power less frequently.

actual cases fall either clearly within or without the federal question statute."); William Cohen, The Broken Compass: The Requirement That a Case Arise "Directly" Under Federal Law, 115 U. PA. L. REV. 890, 905-06 (1967) ("The bulk of federal civil litigation in the federal courts presents no jurisdictional problem."); Wasserman, supra note 175, at 589-90; Wasserman, supra note 23, at 697-98. Much of the confusion over "arising under" comes where state law creates the cause of action, but a "substantial" federal question is present within the case. See Grable \& Sons v. Darue Eng'g \& Mfg., 545 U.S. 308, 312 (2005); Wasserman, supra note 175, at 586 n.59.

223. See Pfander, supra note 12, at 224 ("When Congress creates a new federal cause of action... state and federal courts can both hear the claims.").

224. See Wasserman, supra note 23, at 676-77 (arguing that Congress establishes jurisdiction "on an understanding that extant or future statutes enacted under its substantive powers ... provide a cause of action that federal courts now are empowered to hear"); see also Sosa v. Alvarez-Machain, 542 U.S. 692, 714 (2004) (stating that the Alien Tort Statute provided courts with jurisdiction to adjudicate whatever rights were established by federal common law incorporating principles of international law). 
Much has been written about the federal "litigation explosion" that began in the 1970s. ${ }^{225}$ But it is noteworthy that the trigger for that explosion was not the grant of general federal question jurisdiction, which occurred 100 years earlier. ${ }^{226}$ Rather, the trigger was the expansion of substantive federal law, particularly the enactment and interpretation of right-creating statutes governing civil rights, labor and employment, and the environment ${ }^{227}$ and the provision, express or implied, of private causes of action to enforce those new rights. ${ }^{228}$

In other words, changing jurisdiction alone did not change the amount of litigation in federal courts; it was only after enforceable substantive right-duty correlatives expanded that the amount of litigation expanded, even while federal question jurisdiction remained largely unchanged. $^{229}$ It follows that the amount of litigation will be limited

225. See Marc Galanter, The Turn Against Law: The Recoil Against Expanding Accountability, 81 TEX. L. REV. 285, 292-93 (2002) (discussing origins of fears of "litigation explosion" during 1970s); Marc Galanter, The Day After the Litigation Explosion, 46 MD. L. REV. 3, 5 (1986) (describing the "litigation explosion" or "hyperlexis" reading of modern American life, under which more litigation is filed in American courts); see also Siegel, supra note 117, at 1114 (arguing that Rehnquist Court jurisprudence can be understood as reflecting a hostility to, and an effort to limit, private litigation).

226. See REDISH, supra note 3, at 96 (stating that Congress established general federal-question jurisdiction in 1875); Mishkin, supra note 168, at 157 (same).

227. See Mishkin, supra note 168, at 157 (describing the "expanding scope of federal legislation" and its connection to the power of federal courts); Resnik, supra note 2, at 1004 (arguing that, post-New Deal, "the Supreme Court generally found that Congress had the power to make an array of issues 'federal,' thus enabling growth of the federal courts' docket"); see also, e.g., Civil Rights Act of 1964, 42 U.S.C. $\S \S 2000 \mathrm{e}-2000 \mathrm{e}-17$ (2000); Age Discrimination in Employment Act of 1968, 29 U.S.C. $\S \S 651-678$ (2000); Americans with Disabilities Act of 1990, 42 U.S.C. $\S 12182$ (2000); Voting Rights Act of 1965, 42 U.S.C. $\S \S 1973-1973$ aa-6; Clean Water Act of 1977, Pub. L. No. 95-217, 91 Stat. 1566 (1977); Maine v. Thiboutot, 448 U.S. 1, 4 (1980) (holding that $§ 1983$ supports claims for violations of federal statutes); Monell v. Dep't of Soc. Servs., 436 U.S. 658, 690 (1978) (holding that municipalities are "persons" for purposes of $\S 1983$ ); Griggs v. Duke Power Co., 401 U.S. 424, 429-30 (1971) (holding that Title VII prohibited employment programs having racially discriminatory effect); Monroe v. Pape, 365 U.S. 167, 184-87 (1961) (establishing expansive definition of "under color of state law" in $\S 1983$ to permit claims against state government officials who violate state law), overruled on other grounds by Monell, 436 U.S. at 701.

228. See, e.g., Cannon v. University of Chicago, 441 U.S. 677, 709 (1979) (holding that factors support finding of implied private cause of action to enforce Title IX of the Education Amendments of 1972); Bivens v. Six Unknown Named Agents of Fed. Bureau of Narcotics, 403 U.S. 388, 397 (1971) (recognizing right to recover damages for violations of constitutional rights by federal officers). But cf. Correctional Serv. Corp. v. Malesko, 534 U.S. 61, 75 (2001) (Scalia, J., concurring) (criticizing "heady days" in which the Supreme Court assumed common law powers to create causes of action).

229. In 1980, Congress eliminated an amount-in-controversy requirement from $\S 1331$, marking a slight expansion in the scope of jurisdiction under the general federal question grant. Federal Question Jurisdictional Amendments Act of 1980, Pub. L. No. 96-486, § 2(a), 94 Stat. 2369. See also Arbaugh v. Y \& H Corp., 546 U.S. 500, 505 (2006) (discussing this change). But most modern right-creating statutes contained their own jurisdictional grants, giving the courts power to hear cases "brought under" those statutes regardless of the amount in controversy. See, e.g., 42 U.S.C. \& 2000e-5(f)(3) (2000) (granting federal jurisdiction over claims "brought under" substantive 
most effectively by diminishing substantive rights and the ability to privately enforce those rights, rather than diminishing judicial jurisdiction simpliciter. In fact, jurisdiction and litigation need not move in the same direction. While Siegel describes the late Rehnquist Court as limiting the institution of litigation by limiting various substantive doctrines, ${ }^{230}$ Steven Vladeck points out that the Court simultaneously took an expansive view of judicial power in interpreting federal jurisdictional grants. ${ }^{231}$

\section{Grave Questions of Authority}

A final difference goes to the foundational constitutional structure and the question of what legal rule makers are authorized to do. Jurisdiction stripping raises "grave questions about Congress' authority" to impinge upon judicial jurisdiction. ${ }^{232}$ It is the subject of longstanding doctrinal and theoretical controversy. ${ }^{233}$ Objections to congressional threats are grounded in the text and structure of the Constitution, ${ }^{234}$ separation of powers, ${ }^{235}$ judicial independence, ${ }^{236}$ the essential role of

provisions of Title VII); 28 U.S.C. $§ 1343$ (a)(3) (2000) (granting federal jurisdiction over claims brought under $\S 1983$ ). Thus, it is unlikely that federal courts were able to hear cases after the 1980 amendment that they otherwise could not have heard under the prior rule. But cf. Thiboutot, 448 U.S. at 8 n.6 (accepting, under old version $\S 1331$, that there are some statutory claims that could have been brought under $\S 1983$, but for which there would have been no federal jurisdiction unless the amount-in-controversy requirement of $\S 1331$ was satisfied).

230. Siegel, supra note 117, at 1117 ("In myriad ways, the Court has made life very difficult for civil plaintiffs.").

231. See Steven I. Vladeck, The Increasingly "Unflagging Obligation": Federal Jurisdiction After Saudi Basic and Anna Nicole, 42 TULSA L. REV. 553, 553 \& n.4 (2007) (noting that the trend toward expanding jurisdictional grants "comes notwithstanding the general substantive hostility to litigation that some have found as a consistent pattern in the jurisprudence of the Rehnquist Court").

232. Hamdan v. Rumsfeld, 126 S. Ct. 2749, 2763-64, 2769 (2006) (holding that jurisdictionstripping provision did not apply retroactively to pending cases, in part to avoid such "grave questions").

233. See Amar, supra note 1, at 1499-1500 ("From the First Judiciary Act on, this question has periodically occupied center stage in the high drama of national politics."); Gunther, supra note 1, at 896 ("Jurisdiction-curbing proposals have surfaced in Congress in virtually every period of controversial federal court decisions.").

234. See, e.g., Amar, supra note 3, at 229-30 (synthesizing requirements of Article III into the requirement that some Article III court must have the power to resolve finally federal questions and admiralty issues).

235. See Eisenberg, supra note 3, at 498 (describing struggle over congressional jurisdiction as "recurrent example" of separation of powers generating interbranch conflict).

236. See Ferejohn \& Kramer, supra note 2, at 977 ("[I]ndividual judges may be subject to indirect pressure through threats to deprive their court of resources or to curtail its jurisdiction."); Sager, supra note 3, at 67 (arguing that judicial independence requirements of Article III require some effective form of Article III federal judicial review for claims of constitutional right). Charles G. Geyh remarked:

To the extent that Congress has, as a matter of "constitutional custom," declined to 
courts in the constitutional order, ${ }^{237}$ due process, ${ }^{238}$ and the practicalities of modern American constitutional society. ${ }^{239}$

The Supreme Court never has directly confronted the question of congressional power. ${ }^{240}$ And commentators are all over the map. ${ }^{241}$ Blatant jurisdiction strips such as the Constitution Restoration Act or the We the People Act - bills that carve specific controversial areas of constitutional law out of otherwise broad general federal-question jurisdiction-historically have not gone anywhere. ${ }^{242}$

Regardless of how the jurisdiction-stripping debate resolves itself, situations in which statutory and constitutional rights are rendered nonextant do not raise similar "grave questions" about legal rule-making authority. The illustrations of non-extant rights in this Article all are products of the exercise of unquestioned power in some legal decision maker to establish substantive legal rules and norms. ${ }^{243}$ Congress clearly is the master of whether to exercise its lawmaking powers and of the scope of rights and duties established in such legislation, at least within constitutional bounds. Courts, vested with the power of juridical review, properly wield authority (putting to one side whether that authority is

impeach unpopular judges, to court-pack, or jurisdiction-strip because it has long regarded such practices as antithetical to Article III independence, the stature and stability of Congress's self-restraint is logically enhanced. While Congress remains free to overlook or override its customs and precedents, decisions to do so must first overcome the presumption that such action is contrary to the Constitution as Congress has traditionally construed it.

Geyh, supra note 4, at 165-66.

237. See Hart, supra note 3, at 1365 (describing the "essential role of the Supreme Court in the constitutional plan"); Sager, supra note 3, at 43 (discussing federal courts' responsibility to "ensure state compliance with federal constitutional norms").

238. See REDISH, supra note 3, at 42 (arguing that due process requires that litigants have an independent forum for the adjudication of constitutional rights).

239. See Eisenberg, supra note 3, at 504 (arguing that "changing circumstances" and "other constitutional realities" compel the existence of lower federal courts with jurisdiction to perform "critical functions" in resolving federal issues); Gunther, supra note 1, at 921 (arguing that jurisdiction-stripping proposals should be rejected "because they are unwise and violate the 'spirit' of the Constitution, even though they are ... within the sheer legal authority of Congress").

240. See Pfander, supra note 12, at 194 ("[W]e know little about how the Court might analyze the [jurisdiction-stripping] legislation.").

241. Supra notes 3-4.

242. See Ferejohn \& Kramer, supra note 2, at 988 ("The chronic failure of these efforts to divest federal courts of jurisdiction easily could mislead one into believing that Congress cannot, as a practical matter, effectively control federal judges by regulating their jurisdiction."); Sager, supra note 3, at 20 (arguing that, although jurisdiction-stripping measures have been proposed, "Congress has almost always repudiated such efforts"). But see Pfander, supra note 12, at 194 (suggesting current trends perhaps show increased congressional tolerance for strippping measures); supra notes 9-12 and accompanying text.

243. See Walt, supra note 29. 
supreme, exclusive, or final ${ }^{244}$ ) to interpret the scope and meaning of constitutional provisions, particularly right- and liberty-granting provisions such as the First Amendment. ${ }^{245}$ Judicial review necessarily compels courts to police the boundaries of congressional power, measuring congressional legislation against those boundaries, and rejecting legislation that exceeds them. ${ }^{246}$

One can, of course, disagree with the scope of resulting rights, on a normative argument that the Constitution, justice, or both demand a certain level of rights and liberties. ${ }^{247}$ One can disagree with constitutional doctrine that produces particular outcomes and particular understandings of federal constitutional law. ${ }^{248}$ One can believe that the federal government ought not affect or alter the existence of common law rights, but should leave the issue to other sovereign legal rule

244. See KRAMER, supra note 5, at 8 ("Final interpretive authority [over the Constitution] rested with 'the people themselves,' and courts no less than elected representatives were subordinate to their judgments."); Whittington, supra note 68, at 782 ("Even where the judiciary is active and retains the ultimate authority to settle the issue, nonjudicial actors may well engage in a 'dialogue' with the Court over the most appropriate interpretation of the Constitution, encouraging the Court to adjust its doctrines to accommodate other views.").

245. See SAGER, supra note 63, at 70 ("Particularly in its liberty-bearing provisions, the Constitution offers broad structural propositions and moral generalities, and the judiciary has by and large accepted the obligation to fill in these general stipulations with concrete applications, to fashion workable and defensible conceptions of the Constitution's moral concepts."); Curtis, supra note 68, at 315-16 (arguing that James Madison emphasized judicial enforcement and guardianship of rights as a way to make the Bill of Rights effective); Louise Weinberg, Our Marbury, 89 VA. L. REV. 1235, 1393-94 (2003) (arguing that Marbury ultimately is about the establishment of judicial review of government misconduct); see also Marbury v. Madison, 5 U.S. (1 Cranch) 137, 177 (1803) ("It is emphatically the province and duty of the judicial department to say what the law is."); THE FEDERAList No. 78, at 492 (Alexander Hamilton) (Benjamin Fletcher Wright, ed., 1961) ("A constitution is, in fact, and must be regarded by the judges, as a fundamental law. It therefore belongs to them to ascertain its meaning, as well as the meaning of any particular act proceeding from the legislative body.").

246. See Lynn A. Baker, Putting the Safeguards Back into the Political Safeguards of Federalism, 46 VILL. L. REV. 951, 972 (2001) ("Substantive judicial review of federalism issues is necessary both to remind Congress of its own obligation to restrain itself, and to catch any particularly egregious examples of federal overreaching . ..." (citation omitted)).

247. See Daniel M. Berman, A Bill Becomes a Law: The Civil Rights Act of 1960, 117 (1962) (describing Thurgood Marshall's criticism of weak rights created by the Civil Rights Act of 1960); William E. Forbath, The New Deal Constitution in Exile, 51 DUKE L.J. 165, 176 (2001) (describing New Deal arguments that "citizens had fundamental economic and social rights under the Constitution ... a and Congress, therefore, had the duty to exercise its power to govern economic and social life in a way that sought to secure those rights"); Lawrence G. Sager, Justice in Plain Clothes: Reflections on the Thinness of Constitutional Law, 88 Nw. U. L. REV. 410, 421 (1993) ("[G]overnment is obliged to energetically pursue the effacement of injustice's entrenched consequences.").

248. See, e.g., Post \& Siegel, supra note 131, at 524 (criticizing Court's decision in Morrison for its "refusal to entertain the possibility of systemic constitutional wrong"); Smolla, supra note 141, at 1145 (arguing that there was "a lameness to the assertion [in Bartnicki] that anytime an otherwise private conversation implicates matters of public concern, freedom of speech must trump the right to privacy"). 
makers. ${ }^{249}$ There is particular controversy over Morrison-type judicial enforcement of the internal limits on congressional power in the name of constitutional federalism. $^{250}$ But none of these objections goes to the essential structural power of legal rule makers to dictate the existence of substantive rights and duties. ${ }^{251}$

In fact, limiting and eliminating rights is a more appropriate way to control courts and parties because it is more transparent than jurisdiction stripping. To eliminate rights, the relevant rule maker must make obvious in its legal pronouncement that substantive rights are being diminished or eliminated and what the remaining rights will be. If the goal and result is diminishment, non-existence, or non-enforcement of some rights, the legal rule maker must say so. ${ }^{252}$ It cannot play what commentators call a "political shell game"-deceiving the public as to the actual state of legal rights by manipulating process to achieve a result rather than dictating the result by changing substantive legal rules. ${ }^{253}$ This transparency, at least in theory, enhances democratic accountability; the public better understands what has been done to substantive law and can hold the rule maker (at least Congress or the President) to answer for unpopular limits on rights, liberties, and duties. ${ }^{254}$

249. See, e.g., Kairys, supra note 119, at 950 (arguing that federal laws cutting into state common law rights "undercut coherent and consistent rules and sacrifice basic fairness for the expediency of the well connected").

250. Compare Kramer, supra note 126, at 287 ("[T] historically exercised no or virtually no effective review, of which patrolling the limits of Congress's power vis-á-vis the states has been the foremost example throughout our history."), and Post \& Siegel, supra note 131, at 502 (arguing that the Court's vigorous protection of federalism ignores the fact that "Americans now believe that a core function of the federal government is to prohibit discrimination in the public and private sectors"), and Herbert Wechsler, The Political Safeguards of Federalism: The Role of the States in the Composition and Selection of the National Government, 54 COLUM. L. REV. 543, 558 (1954) ("[T]he national political process in the United States-and especially the role of the states in the composition and selection of the central government-is intrinsically well adapted to retarding or restraining new intrusions by the center on the domain of the states."), with Lynn A. Baker \& Ernest A. Young, Federalism and the Double Standard of Judicial Review, 51 DuKE L.J. 75, 134 (2001) (“A state's freedom from federal interference, like an individual's freedom from governmental restrictions on expression or private choices, is an essentially negative freedom.") See also supra notes 127-39 and accompanying text; $c f$. Sager, supra note 69, at 1365-66 (arguing that constitutional federalism is the area in which Beta disagreements about the content of the Constitution morph into Alpha disagreements).

251. Cf. Gunther, supra note 1, at 921 (arguing that jurisdiction-stripping proposals should be rejected "because they are unwise and violate the 'spirit' of the Constitution, even though they are ... within the sheer legal authority of Congress").

252. See Eisenberg, supra note 3, at 521 (describing suspicion of jurisdictional statutes that attempt to control judicial results rather than dockets).

253. Martin H. Redish \& Christopher R. Pudelski, Legislative Deception, Separation of Powers, and the Democratic Process: Harnessing the Political Theory of United States v. Klein, $100 \mathrm{Nw}$. U. L. REV. 437, 450 (2006).

254. See id. at 454-55 ("When Congress simultaneously alters the essence of a substantive law 
This contrasts with hidden limitations on rights affected by jurisdiction strips. For example, the Detainee Treatment Act of $2005^{255}$ included the so-called McCain Amendment, which sweepingly created a right for detainees in United States military custody to receive certain minimum levels of humane treatment and to be free from "cruel, inhuman, or degrading treatment or punishment." 256 This imposed on the United States and its officers a correlative duty to refrain from engaging in cruel, inhuman, and degrading treatment. But in separate provisions in the DTA and the subsequent Military Commissions Act of 2006, ${ }^{257}$ Congress stripped federal courts of jurisdiction to hear any claims that those rights had been violated or that the United States had ignored the duties imposed. ${ }^{258}$

A direct attack on claim-rights also is more likely to achieve the desired result than an indirect attack on jurisdiction. With respect to statutory rights, Congress has the ultimate word on the scope and meaning of statutory rights. ${ }^{259}$ It can diminish rights in response to overly expansive judicial interpretations ${ }^{260}$ and it can expand rights in response to overly narrow judicial interpretations. ${ }^{261}$ Congress has a freer hand (within constitutional bounds) to override and narrow (or expand) common law rights and duties, because common law exists solely at the sufferance of the legislature and lasts only as long as Congress or a state legislature approves of the policy reflected in common law rules. ${ }^{262}$

On the other hand, the modern constitutional understanding precludes Congress or the President from defining constitutional meaning, at least as a final matter and at least as to questions on which the courts have determined that Congress or the President lacks particular

through procedural or evidentiary means, the legislators' vote on the substantive portion of the law is effectively a sham.").

255. Detainee Treatment Act of 2005, Pub. L. No. 109-148, 119 Stat. 2739 (2005).

256. Id. $\S 1003$ (codified at 42 U.S.C.A. § 2000dd(a) (2006)).

257. Pub. L. No. 109-366, 120 Stat. 2600 (2006).

258. See id. $\S 1005(\mathrm{e})(1)$ (codified at 28 U.S.C.A. $\S 2241$ (e)(1) (2006)); supra note 8.

259. Ferejohn \& Kramer, supra note 2, at 965 ("If the legislature changes the applicable law, for example, judicial decisions obviously ought to reflect this fact.").

260. See supra notes $96-98$ and accompanying text.

261. See, e.g., Civil Rights Act of 1991, Pub. L. No. 102-166, 105 Stat. 1072 (1991) (codified in various sections of United States Code); Landgraf v. USI Film Prods., 511 U.S. 244, 250-51 (1994) (discussing several Supreme Court decisions the 1991 Act was intended to overturn); Eskridge, supra note 94, at 333 \& n. 4 (listing twelve Supreme Court decisions overridden by the Act). Compare, e.g., Patterson v. McLean Credit Union, 491 U.S. 164, 171 (1989) (holding that 42 U.S.C. $\S 1981$ did not prohibit race discrimination during the performance of a contract), with 42 U.S.C. $\S$ 1981(a) (2000) (redefining discrimination in making and enforcing of contracts to prohibit discrimination in enforcement).

262. See Peters, supra note 114, at 769; supra notes 114-20 and accompanying text. 
power. ${ }^{263}$ For example, the Court has determined that certain government-sponsored religious displays violate the Establishment Clause. $^{264}$ Congress and the President cannot declare that all religious displays, even coercive or endorsing ones, are constitutionally permissible. Congress's only alternative is to attack federal judicial subject matter jurisdiction, taking constitutional cases away from the federal courts and shifting them into (hopefully more receptive, from Congress's standpoint) state courts. ${ }^{265}$

Of course, jurisdiction stripping achieves the desired result of narrowing or eliminating constitutional rights and liberties only if all or a substantial number of state high courts depart from controlling Supreme Court precedent. ${ }^{266}$ If many state courts continue to abide by precedent, substantive First Amendment law remains unchanged.

In an attempt to avoid this barrier to the effectiveness of jurisdiction stripping, the Constitution Restoration Act (from the 109th Congress) explicitly provided that federal court precedent on governmental acknowledgement of God was not binding on state courts. ${ }^{267}$ The bill's proponents obviously sought to signal to state courts their preferred substantive law and to give the courts greater decisional freedom. ${ }^{268}$ But James Pfander argues that such a provision constitutes an invalid interference with the courts. State courts hearing federal cases should be understood as having been constituted, via appointment, as federal tribunals that are "inferior to the Supreme Court," on par with lower federal courts. ${ }^{269}$ The obligation of inferiority to the Supreme Court

263. See City of Boerne v. Flores, 521 U.S. 507, 519 (1997) (rejecting congressional power to decree the meaning of the substantive provisions of the Fourteenth Amendment); supra note 69 and accompanying text.

264. See McCreary County v. ACLU, 545 U.S. 844, 864 (2005) (display of Ten Commandments in courthouse); County of Allegheny v. ACLU of Greater Pittsburgh, 492 U.S. 573, 590-91 (1989) (crèche and other religious symbols in county building); see sources cited supra note 178.

265. See KRAMER, supra note 5, at 249, 250-51 (arguing that some of the most admired Presidents and Congresses turned to blunt political tools, such as jurisdiction stripping, only after the judicial power expanded and created the need to create some degree of control and accountability).

266. Compare Sager, supra note 3, at 41 (arguing that manipulating jurisdiction to check federal courts "offers no control over the state courts," which continue to be bound by existing Supreme Court precedent), with Gerhardt, supra note 11, at 1282-83 (expressing fear that pushing constitutional cases into state court allows state courts to effectively overrule Supreme Court decisions).

267. Constitution Restoration Act of 2005, S. 520, 109th Cong. § 301 (2005); supra note 9 and accompanying text.

268. Sager, supra note 3, at 68-69 (arguing that state courts are particularly vulnerable as adjudicative forums in the face of the "obvious desire of Congress that disfavored claims be repudiated").

269. Pfander, supra note 12, at 212 (citing U.S. ConST. art. III, § 8, cl. 9). 
requires state courts, while acting as inferior federal tribunals, to give effect to the decisions of the Supreme Court. ${ }^{270}$

\section{CONCLUSION}

Jurisdiction is a word of "many, too many meanings.",271 Jurisdiction stripping becomes a phrase of many, too many meanings when courts and commentators too-readily "loosely but realistically",272 equate jurisdiction stripping with any and all legal rules that limit the ability of individuals to recover on federal claims of right in federal court. Jurisdiction stripping also is a loaded and controversial term. Overuse and misuse extends that controversy into matters that should not be subject to structural controversy. Limits on extant constitutional, statutory, and common law rights do limit the ability of individuals to recover on claims of right in federal court. But I have tried to argue that these are not limits on jurisdiction and should not be analyzed, or criticized, as if they are.

The imperative of disentangling jurisdiction stripping from nonextant substantive rights thus is a subset of the imperative of disentangling subject matter jurisdiction from substantive merits of federal rights and federal claims of right. ${ }^{273}$ The law functions better in the courts and as a formalist matter when we recognize and respect these formalist and consequential distinctions between jurisdiction and merits - and the formalist and consequential distinctions between limiting or eliminating jurisdiction and limiting or eliminating substantive rights, liberties, and duties.

270. Id. at 229-30 (arguing that the inferiority requirement requires state courts, acting as federal tribunals, to remain subordinate to the Supreme Court, obliging them to give effect to Supreme Court precedent).

271. Arbaugh v. Y \& H Corp., 126 S. Ct. 1235, 1242 (2006) (quoting Steel Co. v. Citizens for a Better Env't, 523 U.S. 83, 90 (1998)).

272. Weinberg, supra note 13, at 1407-08.

273. See Wasserman, supra note 23 , at 644-45. 